\title{
THE STATE COMPETITION DEBATE IN CORPORATE LAW
}

\author{
Roberta Romano*
}

A perennial issue in corporate law reform is the desirability of a federal system. For notwithstanding the invasive growth of regulation by the national government, principally through the federal securities laws, corporate law is still the domain of the states. While no two corporation codes are identical, there is substantial uniformity across the states. Provisions typically spread in a discernible S-shaped pattern, as one state amends its code in response to another state's innovation. ${ }^{1}$ The revision process is often analogized in the academic literature to market competition, in which states compete to provide firms with a product, corporate charters, in order to obtain franchise tax revenues. ${ }^{2}$ This characterization is the centerpiece of the federalism debate in corporate law-whether competition, and hence a federal system, benefits shareholders. The hero-or culprit-in the debate is Delaware, the most successful state in the market for corporate charters.

Delaware's preeminence and its impact on who benefits from competition is the subject of this paper, which is essentially a survey of the recent learning on state competition. After a sketch of the conventional moves in the state competition debate, I summarize a transaction cost explanation for Delaware's success. Next, I briefly examine a controversial subset of state laws-antitakeover statuteswhose problematic place in corporation codes muddies the debate.

- Professor of Law, Yale Law School. I would like to thank Rick Antle, Lucian Bebchuk, Bob Clark, Henry Hansmann, Lewis Kornhauser, Saul Levmore, Isaac Meilijson, George Priest, Jeff Strnad, Elliott Weiss, Oliver Williamson and participants at workshops at the Northwestern and Yale Law Schools and at the Benjamin N. Cardozo School of Law Conference on The Forces Shaping Corporate Law, and the Harvard Law School Conference on the Economics of Corporate and Capital Markets Law, for helpful comments and suggestions.

1 See Romano, Law as a Product: Some Pieces of the Incorporation Puzzle, 1 J.L. Econ. \& Org. 225, 233-35 (1985). The enactment of general incorporation statutes in the 19th and early 20 th centuries follows a pattern similar to what we observe today. See Shughart \& Tollison, Corporate Chartering: An Exploration in the Economics of Legal Change, 23 Econ. Inquiry 585 (1985). A recent graphic example of statutory invention and imitation is Maryland's second generation takeover statute which requires a supermajority vote in certain business combinations. Md. Corps. \& Ass'ns Code Ann. §§ 3-601 to -603 (1985 \& Supp. 1986). This statute was enacted in 1983 and in less than two years had been adopted by nine other states.

2 See, e.g., Winter, State Law, Shareholder Protection, and the Theory of the Corporation, 6 J. Legal Stud. 251, 255 (1977). 
Thereafter, I review the findings of empirical studies that have sought to arbitrate the state competition debate by employing financial econometric techniques. Having evaluated the literature, I take a final look at state competition by investigating two parameters of importance to any legal system-optimality and stability-through a simple, if not crude, stochastic model of the evolution of a corporate charter market. I conclude by discussing the implications of this new learning on state competition for public policy.

\section{The State Competition Literature}

\section{A. The Classic Positions Revisited}

The foundation of the federalism debate in corporate law is that revenues derived from franchise taxes provide a powerful incentive for state legislatures to implement corporation codes that will maintain the number of domiciled corporations, if not lure new firms to incorporate in their state. All participants in the debate believe that the income produced by the chartering business spurs states to enact laws that firms desire. ${ }^{3}$ This behavioral assumption is plausible: There is a positive linear relation between the percentage of total revenues that states obtain from franchise taxes and states' responsiveness to firms in their corporate codes. ${ }^{4}$ The more dependent a state is on income from franchise tax revenues, the more responsive is its corporation code. The potential revenue from this tax source can be substantial for a small state. Delaware's franchise tax revenue averaged 15.8 percent of its total revenue from 1960-1980, and while it is impossible to generate a precise figure, this income considerably outdistances the cost of operating its chartering business. ${ }^{5}$

Given the shared assertion that revenues compel states to be responsive to firms' demands for legislation, the crux of the dispute is, therefore, whether this responsiveness is for the better. Because of the separation of ownership and control in the management of many large public corporations, when a firm's managers propose a reincorporation or urge the enactment of a statute, no less the adoption of a charter provision, we are concerned about whether they are maximizing the value of the firm. This is the classic agency problem, which goes to the heart of corporation law in a pluralist democracy: How do principals-the shareholders-ensure that their agents-the manag-

3 E.g., id. (supporting state codes); Cary, Federalism and Corporate Law: Reflections upon Delaware, 83 Yale L.J. 663 (1974) (supporting national regulation).

4 Romano, supra note 1 , at $239-40$.

5 Id. at 240-42. 
ers-behave faithfully? ${ }^{6}$

Advocates of a national corporation law have termed state competition a race for the bottom because they believe that managers' discretion is unfettered, enabling them to promote laws that are detrimental to shareholders' welfare. ${ }^{7}$ They base this conclusion on a characterization of the statutes and case law of Delaware-which is the most frequent location for a reincorporation-as excessively permissive, by which they mean tilted toward management. Proponents of the current federal system, however, question this phrasing of the issue, typically viewing the agency problem as trivial. They maintain that the many markets in which firms operate-the product, capital, and labor markets-constrain managers to further the shareholders' interests. Accordingly, in their view, conflict between investors and managers over the content of state laws is largely illusory, and the laws that are promulgated can best be explained as mechanisms for maximizing equity share prices.

The initial articulation of the market argument in the state competition debate was by Ralph Winter. ${ }^{8}$ Responding to William Cary, who launched the first salvo in the modern debate, ${ }^{9}$ Winter contended that if management chose a state whose laws were adverse to the shareholders' interests, the value of the firm's stock would decline relative to stock in a comparable firm incorporated in a state with valuemaximizing laws, as investors would require a higher return on capital to finance the business operating under the inferior legal regime. This impact in the capital market would affect managers by threatening their jobs. Either the lower stock price would attract a takeover artist who could turn a profit by acquiring the firm and relocating it in a state with superior laws, or the firm would go bankrupt by being undercut in its product market by rivals whose cost of capital would be lower because they were incorporated in value-maximizing states. In either scenario, in order to maintain their positions, managers are compelled, by natural selection, to seek the state whose laws are most favorable to shareholders.

Winter's critique is devastating to Cary's analysis because Cary completely overlooked the interaction of markets on managers' incentives. Yet Cary's position cannot be entirely dismissed: More sophisticated proponents of national chartering can move to another line of

6 See Romano, Metapolitics and Corporate Law Reform, 36 Stan. L. Rev. 923, 928-29, 955-56, 1013-14 (1984).

7 E.g., Cary, supra note 3, at 666.

8 Winter, supra note 2.

9 Cary, supra note 3. 
attack by maintaining that there is a true difference in opinion that turns upon Cary's and Winter's assessments of the disciplining effect of markets on managers. Winter can assume away the agency problem because of his view that the capital market is efficient such that information concerning the impact of different legal regimes is publicly available and fully assimilated into stock prices. In contrast, support for national chartering presupposes a market that is, at best, only weakly efficient, such that it does not digest information concerning legal rules. In addition, even if stock prices accurately reflect the value of different legal regimes, if product markets are not competitive or the costs of takeovers are substantial, then a manager's livelihood may not be jeopardized by the choice of a non-value-maximizing incorporation state. When the debate is phrased in this way, the disagreement is over an empirical question concerning market efficiency, for which, in principle, there is a clean answer.

To be sure, Cary sees a failure not only in financial and product markets, but also in local politics. His recommendation of national standards for corporations implies that the political process at the national level differs fundamentally from that of the states. Cary considers the flaw in Delaware's code to be a function of that state's desire for revenue and the close personal connections between Delaware legislators, judges, and corporate law firms. ${ }^{10}$ The national government certainly would not be as sensitive to franchise tax dollars as would a small state, and practically speaking, there would be no competing sovereigns to attract dissatisfied corporations.

But even if we grant Cary's premise that the states' responsiveness is the source of the problem, the elimination of intergovernmental competition is not necessarily the cure. The hitch in Cary's position is that he leaves unexplained why national legislators in pursuit of reelection would be less susceptible to the political influence of managers for "pet" statutes than state legislators. For why should diffuse and unorganized shareholders be appreciably better able to communicate their views to Congress when they cannot do so to state legislatures? ${ }^{11}$ There are countless pieces of legislation produced by

10 Id. at $690-92$.

11 If the claim is that communication costs are lower when there is only one legislature, the obvious response is that even with state competition, only one state matters, Delaware, where a large number of firms reside. Putting it this way makes clear that competition is the linchpin of the argument. Cary must argue that another state would come to the managers' rescue if shareholder lobbyists succeeded in Delaware, thereby making such expenditures futile, whereas no such alternatives would exist in a national scheme. The transaction cost explanation of state competition discussed infra notes 26-40 and accompanying text suggests that there is friction in the chartering market, involving transaction specific assets that tie together partic- 
pork barrel politics in Congress-the tax code is perhaps the most notable example - and there is no convincing reason to believe that firms' managers would be any less skilled at protecting their interests when it comes to a federal corporation code. ${ }^{12}$

\section{B. An Extension of the Debate: Product Differentiation Stories}

Both Cary's and Winter's explanations of state competition predict a trend toward uniformity across state corporation codes. In addition, they imply a process of constant disequilibrium in which the system swings back and forth between corner solutions: As soon as one state innovates with a new provision, all managers should, theoretically, reincorporate in that state in order to increase firm value (or to entrench themselves in their positions). Then a second state, to avoid losing revenue, should respond by introducing a further innovation, causing all of the firms to migrate to it, and so forth. However, the market for corporate charters is more stable than this. Most firms that relocate do so only once, some never change their incorporation state, and Delaware continues to attract the vast majority of all reincorporations. ${ }^{13}$ Accordingly, although Cary's and Winter's depiction of the competitive process is intuitively appealing, it has the undesirable property of being a disequilibrium rather than an equilibrium story. If we assume optimizing behavior, as Winter and Cary assume of managers, a disequilibrium story is unsatisfactory because it implies that deals could still be made between firms and states, and consequently, that the actors have not optimized.

Recognizing this snag in the classic exposition of the corporate charter market, some scholars sought to refine Winter's explanation of the value-maximizing properties of state competition. Richard Posner and Kenneth Scott, in a short note in their corporate law reader, hypothesized that states differentiate their products by tailor-

ular states and firms, and that prevents overnight shifts in a state's market share while simultaneously protecting firms' interests in a responsive corporation code.

12 See generally Y. Aharoni, The No-Risk Society 24 (1981) (public policy is the result of an interplay of organized interest groups); M. Fiorina, Congress: Keystone of the Washington Establishment 41-49 (1977) (desire for reelection spurs congressmen to meet constituents' demands for services). More important, congressmen are responsive to interest groups that are constituency-based rather than Washington-based lobbyists. M. Hayes, Lobbyists and Legislators: A Theory of Political Markets 49-50 (1981) (citing J. Kingdon, Congressmen's Voting Decisions 145-46 (1973)).

13 Romano, supra note 1, at 244 ( $82 \%$ of reincorporations of publicly traded firms in the period 1960-1980 were in Delaware). In my sample of firms, those with multiple reincorporations consisted primarily of a group of Michigan manufacturing companies that went to Delaware in the 1960's and 1970's upon Delaware's revision of its corporation code, and then moved back to Michigan in the 1980's after a change in that state's taxation. Michigan had also revised its code to duplicate Delaware's in the interim. Id. at 258. 
ing their codes to attract different types of firms. ${ }^{14}$ In particular, they suggested that Delaware specializes in providing charters for large publicly traded firms. While this is an interesting insight, there are serious difficulties with it. First, competition is not necessary for product differentiation because it can be achieved within one state's code. Many states, including Delaware, offer different rules for smaller, closely held corporations through the enactment of close corporation statutes. ${ }^{15}$ Second, only slightly more than one-half of the largest firms are incorporated in Delaware. Thus, to be useful, Posner and Scott's conjecture must be refined, as size alone is not a distinguishing characteristic. However, comparison tests across numerous attributes of large public firms incorporated in Delaware and in other states fail to show any statistically significant differences. ${ }^{16}$ Consequently, Posner and Scott's speculation is, at best, incomplete.

While a specialization story avoids a disequilibrium result, it does not provide the normative edge for asserting that state laws are value-maximizing: The welfare implications of product differentiation models are indeterminate, as their equilibrium need not be optimal. ${ }^{17}$ A product differentiation story that fits the formal economic models of the Posner and Scott intuition accordingly does not have to be attached to the position that state laws are in the interest of shareholders. In fact, Barry Baysinger and Henry Butler have combined a product differentiation explanation with pieces of both sides of the state competition debate. ${ }^{18}$ They begin by agreeing with Cary that some state codes, such as Delaware's, are lax and favor managers, while others are strict and favor shareholders. The analysis then takes an interesting turn. Baysinger and Butler's thesis is that firms will locate in the state whose laws match their shareholders' needs: In particular, firms with diffuse ownership will select lax states because these shareholders can sell their shares if management's performance

14 R. Posner \& K. Scott, Economics of Corporation Law and Securities Regulation 111 (1980). A fuller exploration of such a view of corporate charters derived from an economic theory of federalism-Charles Tiebout's theory of local public goods in which citizens move to the locality whose tax and spending program matches their preferences-was provided by Frank Easterbrook. Easterbrook, Antitrust and the Economics of Federalism, 26 J.L. \& Econ. 23 (1983).

15 E.g., Del. Code Ann. tit. 8, 3342 (1984).

16 Romano, supra note 1 , at $262-65$. The only statistically significant differences were that the Delaware firms have been in existence for fewer years than non-Delaware firms and that they average more acquisitions over their shorter lives. Id. This difference can be explained by the transaction explanation of reincorporation, see infra notes 26-40 and accompanying text.

17 See Spence, Product Selection, Fixed Costs, and Monopolistic Competition, 43 Rev. Econ. Stud. 217, 231-33 (1976).

18 Baysinger \& Butler, The Role of Corporate Law in the Theory of the Firm, 28 J.L. \& Econ. 179 (1985). 
is poor, while firms with a controlling shareholder or concentrated ownership will choose strict states whose codes facilitate shareholder activism because exit is costly for large shareholders.

Baysinger and Butler sought support for this self-selection thesis by examining the ownership concentration of firms in states with strict and lax laws. They compared the mean holdings of various types of shareholders across firms that had remained in and firms that had reincorporated away from four states that were classified as strict. Rather than deriving the classification from the content of state corporation codes, upon which the point of the exercise is premised, they defined a strict state to be a state from which headquartered firms migrate. They found that the shareholder groups' holdings were significantly smaller in firms that had left the strict states.

Unfortunately, their definition of strictness is unsatisfactory; a migration index of strictness is a noisy signal because some states have larger firm populations than others, which generates some movement independent of the relative differences in legal regimes. Although Baysinger and Butler alleviate this problem by using percentages rather than absolute numbers of firms per state, the adjusted criterion is still an inaccurate proxy for what they want to measure. One of the four states they identified as strict by the migration criterion, New York, is in fact a relatively permissive state, and a number of states with high corporate retention rates that are permissive under Baysinger and Butler's definition, such as South Dakota, are strict states if we examine the actual content of their codes. ${ }^{19}$ This objection is not trivial. Because the sample for testing their thesis consisted of an equal number of firms from each of the four states they classified as strict, the misclassification of one state renders one-quarter of the observations questionable, and we cannot be sure what effect this has on their results. ${ }^{20}$

More important, Baysinger and Butler's thesis is problematic because it calls for behavior that is not observed. If legal regime and

19 I have developed a measure of states' corporate law responsiveness that is a function of both the substance and timing of enactment of corporation code provisions in order to better examine the state competition hypothesis. See Romano, supra note 1, at 233-42. The responsiveness measure identifies strict and lax legal regimes more precisely than migration because it is derived directly from the content of corporation codes.

20 An additional difficulty is that we do not know whether the variable for director and officer holdings excludes family members who are also managers. Presumably, the tests controlled for such individuals. If not, then the finding of no difference in management holdings would be misleading. Moreover, the conclusion that strict laws are important for firms with higher family holdings would be illusory because if family members are also managers, then the basis for maintaining that the legal regime matters is eliminated because there is no separation of ownership and control in such firms. 
shareholder concentration are paired, as they maintain, then when a firm is taken over and ownership becomes more concentrated, it should move to a strict state. Yet this rarely occurs. In the cases where we see a change of incorporation state at the same time or shortly after a merger, the destination state is typically Delaware, the most "lax" state. ${ }^{21}$

In addition, reincorporation patterns raise a further question concerning their results. Because corporations reincorporate in order to undertake specific types of transactions for which legal rules matter, ${ }^{22}$ if there is a systematic relation between transaction type and ownership concentration, this would create an omitted variable problem, weakening the power of Baysinger and Butler's test. For the type of legal regime, strict or permissive, might actually be related to the transaction motivating the reincorporation and not to the ownership pattern. For example, when firms go public they frequently reincorporate in Delaware. ${ }^{23}$ While this fact superficially appears to further Baysinger and Butler's thesis because the firm moves to a lax state as ownership becomes less concentrated, it in fact underscores a difficulty in testing their explanation-the transaction of interest, reincorporation when going public, coincides with a change in ownership pattern, and thus confounds the test.

Moreover, it is misleading to characterize firms that have gone public as having diffuse ownership, because even though their ownership has become less concentrated when they go public, the original owners retain, at minimum, working control. This phenomenon is therefore an additional problem for their thesis: Since there are still large controlling shareholders, the firm should not have moved to a permissive state. In no case does the original owners' holding drop to a sufficiently small number of shares such that the difficulty of selling the stock that Baysinger and Butler posit would disappear. ${ }^{24}$ Indeed, most of the statistically significant ownership differences in their sample, given conventional wisdom, would not significantly affect share-

21 I found this to be so in the data collected for Romano, supra note 1.

22 Id. at 250-51. See also infra notes 26-28 and accompanying text (discussing transaction costs of reincorporation).

23 Romano, supra note 1 , at 255-56.

24 It might make sense for Baysinger and Butler to emphasize absolute levels of ownership rather than the relative measure of a difference in means test. This would eliminate the problem discussed in the text by excluding most firms that go public. But it would also weaken the link between their thesis and state competition. In their story, it is the preferences of migrating firms that drives the selection of corporation codes. Because going-public firms comprise the largest group of reincorporating firms, id. at 250,253 , to be complete, any theory of state competition must explain those decisions. 
holders' control of their firm. ${ }^{25}$ Furthermore, the mean holding in the leaving firms of all types of shareholders for which the difference across firms was statistically significant is still a very substantial block of stock. Accordingly, these investors do not have the ability to sell shares easily in either case, casting further doubt on Baysinger and Butler's explanation of state competition.

Given these factors, the more plausible explanation for the ownership pattern in conjunction with migration is not that large shareholders necessarily prefer stricter laws, but rather that the initial legal regime may be irrelevant to such shareholders. The corporation code does not have the monitoring role that Baysinger and Butler ascribe to it because for firms with controlling shareholders that move upon going public, as well as for the average firm in their sample, it is not very helpful to talk about the separation of ownership and control. In short, some other feature must be driving corporations to Delaware. While Baysinger and Butler offer an elegant twist-corporate self-selection-to the state competition debate, the data do not satisfactorily accord with their identification and explanation of the basis for selfselection.

\section{A Transaction Cost Explanation of the Market for Corporate Charters}

The feature in Cary's and Winter's analysis that implies system instability is the assumption that there are no transaction costs of moving. If there are costs to reincorporating, then it is less likely that a corner solution will develop. The importance of transaction costs enters into the product differentiation explanations that emphasize variety in corporation codes. It is explicit in Posner and Scott's size hypothesis-they suggest that only large firms can afford to relocate in Delaware. And while it may not be crucial to Baysinger and Butler's thesis, they do maintain that information costs prevent firms from choosing the most liberal state and then tailoring their charters to meet shareholder preferences.

My explanation of the corporate charter market relies on transaction costs. This transaction cost explanation of state competition has two prongs: one concerns the reasons why firms move, and the other concerns the persistence of Delaware's extraordinary market

25 For example, the corporate ownership of "leavers" averages $11.28 \%$, compared to $15.69 \%$ for "stayers." Baysinger \& Butler, supra note 18, at 187. Yet in both situations, the lower percentage is well within what is generally thought to be enough for working control in a public corporation, and constitutes insider status for the purpose of the federal securities laws. 
share. The cost of migration ${ }^{26}$ must produce a commensurate benefit for a move to be undertaken, a benefit that relates to a reduction in the cost of operating the firm under the new regime. In addition, unlike the product differentiation stories, my thesis predicts substantial uniformity in state laws, in keeping with the classic positions of Cary and Winter, as well as the more salient characteristic of corporation codes. Under this explanation, variety in corporation codes is primarily a function of diffusion-the differential in time by which innovations are enacted by legislatures across the states-rather than of different preferences across firms. ${ }^{27}$

\section{Why Do Firms Reincorporate?}

I expected that reincorporations would accompany changes in business operation and organization that would be cheaper in a different legal regime. The cost reduction could involve direct costs-for instance, where the legal rules governing specific transactions differ across the states, thereby imposing different costs on those transactions-or it could involve indirect costs-for example, different regimes affect the likelihood and cost of litigation over transactions differently. My data on reincorporations support this contention: Firms reincorporate when they are preparing to initiate a discrete set of transactions, the most frequent being a public offering, a merger and acquisition program, or defensive maneuvering against takeovers. ${ }^{28}$ A number of legal rules that vary across the states, including the conditions for shareholder voting and appraisal rights, affect the cost of engaging in such activity. For instance, corporation codes may limit merger voting and appraisal rights of the acquiring firm's shareholders, which reduces acquisition costs. They may also regulate takeovers or make charter amendment flexible, reducing the cost of resisting a bid. Finally, different organizational rules, including the requirements for shareholder meetings, written consent and board

26 See Romano, supra note 1 , at $246-49$ (reincorporation costs range from a few thousand to millions of dollars).

27 In my analysis, because most states are behaving defensively in the charter market and differences in legal regimes are of interest to firms undertaking certain types of transactions, firm self-selection could still be a factor in statutory variety in the following circumstance: If no or very few firms in a state will ever undertake specific transactions for which another state has innovated, then the former state does not have to amend its code to retain the firms in its jurisdiction.

28 These three categories comprised $72 \%$ of the reincorporations where an associated transaction type could be identified. Romano, supra note 1 , at 250 . My data consisted of survey responses and public information on the reincorporations of several hundred industrial corporations that were publicly traded in 1982 and had changed their incorporation state during the 20-year period, 1962-1981. Id. at 242-43. 
communication, both ease the transition to, and reduce the cost of operating, a newly publicly traded firm.

In addition, a common characteristic of the transactions motivating reincorporations is an increase in the likelihood that a firm will be embroiled in litigation. Acquisitions and efforts to thwart them frequently produce protracted lawsuits over the fairness of the offer or the appropriateness of management's actions. Going public sets the stage for potential fiduciary breaches by bringing into the firm a new class of stockholders whose interests may differ from those of manager-shareholders. In all of these situations, a legal regime that reduces expected litigation costs is desirable. A well-developed case law and expertise in corporate law are mechanisms by which a state can lower those costs. Such a regime enables counsel to provide management quickly with opinion letters concerning the transactions they wish to pursue, which facilitates business planning to circumvent problems that could spark litigation.

Reincorporating firms' interest in finding legal regimes that reduce their cost of doing business is further supported by survey responses: Firms that reincorporate to undertake the transactions mentioned earlier perceive a significant difference in the laws of the origin and destination states and emphasize that the difference is an important factor in their decision to move more frequently than do other firms. ${ }^{29}$ Moreover, firms that reincorporate to pursue the identified transactions choose more frequently to relocate in the most responsive state, Delaware. ${ }^{30}$ If there is a self-selection story to be told about state competition for corporate charters, it is more likely to be one that matches responsive states with firms engaging in particular types of transactions, which may or may not be correlated with shareholder concentration, rather than firms of specified ownership structures per se.

While the transaction cost explanation of reincorporation tells us why firms change their incorporation state, it is inconclusive concerning who benefits from the move. If firms reincorporate to reduce transaction costs, then migration is value-maximizing for shareholders by definition, because cost minimization is an inherent aspect of equity share price maximization. However, if reincorporation merely

29 Id. at 258 . The other firms moved primarily to realize tax savings. Firms that move to a more responsive state also more frequently report a difference in origin and destination state legal regimes and that the difference is an important factor in their decision to move. The chisquare statistic for both crosstabulations was statistically significant, although the statistic for the table of transaction-type by questionnaire response is not reliable because more than $20 \%$ of the cells had very low expected frequencies. Id. at 258-60.

30 Id. at 255-56. 
reduces potential litigation costs, the direction of the effect becomes muddied. These lawsuits involve shareholder claims, and the beneficiaries of the cost reduction may therefore include managers, who are the defendants in the suit and whose interest in this context may conflict with that of the shareholders. Moreover, even when the cost reduction consists of making a specific transaction cheaper to undertake, the move is value-maximizing only if the transaction itself benefits shareholders. ${ }^{31}$

\section{Why is Delaware the Destination State of Choice?}

The transaction cost explanation of the corporate charter market provides a different perspective on state competition. Delaware's persistent large market share is maintained by a first-mover advantage created by the reciprocal relation that develops between the chartering state and firms due to their substantial investment in assets that are specific to the chartering transaction. The concept of a transaction specific asset, developed by Oliver Williamson, arises in an intertemporal context and refers to an asset that cannot be redeployed in an alternative use at a price anywhere comparable to its value in the original contract should that contract be disrupted. ${ }^{32}$ Contracts involving such assets transform the parties' exchange relationship from a competitive market transaction into a bilateral monopoly. A simple example of a transaction specific asset is the specialized racks that are used to transport finished automobiles to market. Such racks are customized for specific car models and cannot be used to transport models of different manufacturers. As a consequence, they are valuable only in certain transactions, and both transporter and car manufacturer are vulnerable and have holdup power. At the outset, there are a number of transporters and automobile manufacturers with which to negotiate, but once parties enter into an agreement, the manufacturer needs that particular hauler to get its cars to market and the hauler needs that manufacturer to earn a return on the racks.

The key feature for analysis is that the nonredeployable character of the asset makes the parties to a contract vulnerable and necessitates additional institutional arrangements-which Williamson terms "governance structures"- that reduce the possibility of exploitation and safeguard investments in the transaction specific asset. One such

31 Some would argue that particular transactions, such as takeover defensive tactics, do not benefit shareholders. For some discussion of this issue, see infra notes 53-57 and accompanying text.

32 For a complete exposition of the theory, see O. Williamson, The Economic Institutions of Capitalism 163-206 (1985). 
mechanism is the bilateral use of hostages-the contracting party may place him or herself in an analogously vulnerable position to the asset owner by giving up something of value, by posting a bond so to speak. This action credibly guarantees his or her performance and thereby maintains the other party's incentive to invest in the transaction specific asset. ${ }^{33}$ In cases of asset specificity, the exchange of hostages may be a prerequisite for the transaction itself to occur.

How does this analysis apply to the corporate charter market? ${ }^{34}$ Because the transactions between a firm and its incorporation state extend over a long period of time and reincorporation is not costless, relocation makes a firm vulnerable to exploitation by the state. In particular, the state may charge a premium for incorporation and then alter its code or simply not implement the latest innovations, to the firm's detriment, knowing that the firm cannot quickly migrate again without incurring additional expenses. Hence, due to this nonsimultaneity in performance, a state with a favorable corporation code must guarantee its code's continued responsiveness to be successful in the corporate charter market.

Of all the states, Delaware is best positioned to credibly commit itself to responsiveness. First, its very success in the incorporation business serves, ironically, to constrain its behavior: The high proportion of total revenue it derives from franchise taxes guarantees continued responsiveness because it has so much to lose. For unlike states less dependent on franchise revenues, Delaware has no readily available alternative source to which it can turn in order to maintain expenditures. It cannot afford to lose firms to other states by failing to

${ }^{33}$ See id. The typical solution to the automobile racks example discussed in the text involves informal contracting in conjunction with ownership of the racks by the carrier, rather than a bilateral exchange of hostages; the typical solution for the shipment of automobile parts, which also require specialized racks, is ownership by the shipper. Palay, Avoiding Regulatory Constraints: Contracting Safeguards and the Role of Informal Agreements, 1 J.L. Econ. \& Org. 155 (1985). Good examples of pure hostages are far too complex to be useful for the text's pedagogic point of an illustration of a transaction specific asset. For specific examples, see O. Williamson, supra note 32 , at 180-89, 197-203.

34 The discussion in the text sets out the thesis put forth in Romano, supra note 1, at 235 $36,240-42,257-60,273-79$. I state the thesis in detail for those who have not read or do not wish to read the longer article, and for those who did not understand it. In a recent paper, Jonathan Macey and Geoffrey Miller, after citing my article for the data, state that they are offering a new explanation of state competition in which Delaware "offers a reliable promiseone that cannot be matched by its competitors-that its corporation law will remain highly attractive to managers for many years into the future." Macey \& Miller, Interest Groups and Delaware Corporate Law 26 (preliminary draft 1986) (available at Cardozo Law Library). The central insight that they are advancing as their theory of the corporate charter market is precisely that of my earlier article. 
keep its code up-to-date. In this way, Delaware offers itself as a hostage by its reliance on franchise taxes to finance its expenditures.

Second, an additional institutional mechanism warranting responsiveness is Delaware's constitutional provision mandating that all changes in the corporation code be adopted by a two-thirds vote of both houses of the state legislature. ${ }^{35}$ This makes it difficult to renege on provisions already in the code and, correspondingly, on the overall policy of being responsive to firms. While the provision would appear to make future changes equally difficult, if firms are risk averse when it comes to corporation codes, they might favor a maximin strategy in which the constitutional provision would be desirable, since it helps to ensure that the legal regime will never be worse than it is at the time of incorporation. This provision thus complements Delaware's high proportionate franchise tax, for while the constitution is backwardlooking, limiting radical revamping of the code, the incentives provided by the franchise tax revenue are forward-looking, as the state reacts to the high proportion of franchise tax revenues in the past by maintaining its responsiveness to incremental change in the future.

Third, Delaware has invested in assets that have no use outside of the chartering business. These assets, which can best be characterized as legal capital, consist of a store of legal precedents forming a comprehensive body of case law, judicial expertise in corporate law, and administrative expertise in the rapid processing of corporate filings. These features are not as easily duplicated by other states as the provisions of a corporation code because of the startup costs in developing expertise and the dynamic precedent-based nature of adjudication by courts. ${ }^{36}$

The combination of these factors-the high proportion of franchise tax revenue, the constitutional supermajority requirement, and the investments in legal capital - create an intangible asset with hostage-like qualities, a reputation for responsiveness, ${ }^{37}$ that firms

35 Del. Const. art. IX, $\S 1$. Only one other state, Iowa, has such a constitutional provision. Iowa Const. art. $8, \S 12$.

36 While a state could explicitly legislate the principle of statutory construction that when it enacted a Delaware law it intended to include all of the existing judicial interpretations, see, e.g., Wilmington City Ry. v. People's Ry., 47 A. 245, 251 (Del. Ch. 1900), this would not protect firms concerning future adjudicative issues. The state would have to bind its courts to follow future Delaware precedents, and hope that no case of first impression decided by its own courts would conflict with a subsequent Delaware decision. Such a system would involve overwhelming problems of constitutional delegation and parties' rights of appeal, in addition to problems concerning the coherency of local decisional law and the granting of retroactive relief should the hypothesized conflict arise.

37 The connection between reputations and hostages is straightforward: In the corporate charter market where both firms and states have potentially infinite lives, the party with the 
weigh in their incorporation decision. The large number of firms already incorporated in Delaware further solidifies its commanding position in the market by giving it a first-mover advantage. There is safety in numbers-the more firms there are the higher the level of franchise tax paid and the more the state relies on its incorporation business for revenue, which provides the incentive to behave responsively. In addition, the large number of firms makes it more likely that any particular issue will be litigated and decided in Delaware, providing a sound basis for corporate planning. This attracts even more firms for the more responsive a state and the more settled its law, the cheaper it is for a firm to operate under that legal regime. The first-mover advantage is self-sustaining because the more firms there are paying a franchise tax, the greater the return Delaware earns on its reputation for responsiveness, and the stronger its incentive to not engage in an endgame strategy of exploiting firms that would damage, if not destroy, its investment in a reputation.

This brings us to the demand side of the market, which also aids Delaware in maintaining an edge. There is a third party affected by the incorporation system, legal counsel, and the features of Delaware's legal regime that are attractive to firms-a well-developed case law with a pool of handy precedents and a means for rapidly obtaining a legal opinion on any issue-are also advantageous to corporate lawyers. For these features of Delaware law lower the cost of furnishing advice to clients. This is especially important for outside counsel, who service firms that are headquartered in different states, and who are instrumental in choosing the incorporation state. ${ }^{38}$ They realize cost savings by having clients operate under one legal regime. In addition to encouraging the choice of Delaware as the incorporation site for clients, specialization also provides an incentive for advising firms to remain in Delaware, because moving will diminish the attorney's human capital. Counsel's desire to recoup the investment in mastery of the institutional detail of Delaware law ties firms reciprocally to Delaware, just as Delaware is tied to firms.

Human capital is important in another way. Delaware's stake in

reputation, Delaware, has an incentive to maintain it because the costs of building up its reputation will not be recouped if it behaves irresponsively in the short run. For then domestic firms will relocate, new firms will not migrate to it, and tax revenues in later periods will be lost. In other words, a cooperative equilibrium can emerge from a "tit-for-tat" strategy. See generally R. Axelrod, The Evolution of Cooperation (1984) (reciprocity strategies are selfreinforcing and powerful tools to create cooperation).

38 Romano, supra note 1 , at 274-76. Macey and Miller question these results, stating that "the questionnaire ... used did not list investment banks as potential parties to suggest reincorporation." Macey \& Miller, supra note 34, at 25 . The questionnaire included investment bankers as an explicit choice; the respondents did not choose that answer. 
the chartering business exceeds the revenues it receives from the franchise tax. A number of its citizens specialize in providing services to nonresident Delaware corporations. Accordingly, it is in the interest of those individuals that Delaware be responsive to corporations so that the demand for their services does not decline. ${ }^{39}$ Delaware's supermajority constitutional provision therefore serves an important function aside from credibly precommiting it to be responsive to firms: It protects the value of these individuals' personal investments by making it more difficult for a political realignment in the state to alter the longstanding course of corporate responsiveness.

This transaction specific human capital, which creates a "mutual reliance relation" ${ }^{40}$ between firms and Delaware, joins the parties in long-term cooperation because of their reciprocal vulnerability, and cements Delaware's market position, as it makes it difficult for a rival state to compete successfully. Another state cannot simply offer corporations the same code at a lower price and attract the marginal firm, because a switch would increase operating and legal costs, and more importantly, the state cannot provide a credible commitment of superior service. In particular, a rival state cannot place itself in the same vulnerable position as Delaware because it starts from a low franchise tax ratio and has not yet invested in legal capital. ${ }^{41}$ In order for a state to begin to compete, a significant number of firms would

39 Romano, supra note 1, at 276-77. A number of years ago, Joe Bishop made the point concerning the importance of lawyers in Delaware's lack of a security-for-expenses requirement for shareholder derivative suits. He wrote: "It might . . . occur to a cynical mind that this curious anomaly of the Delaware law may not be wholly unconnected with the fact that the prosecution or defense of a derivative suit in a Delaware court requires the retention of Delaware counsel." Bishop, New Cure for an Old Ailment: Insurance Against Directors' and Officers' Liability, 22 Bus. Law. 92, 94-95 (1966). Macey and Miller, supra note 34, also stress the importance of lawyers in Delaware. They appear to suggest that the input of lawyers in Delaware's legislative process has negative implications for a theory of state competition. Such a conclusion would be wrong-the role of lawyers is peripheral to the debate, particularly from the transaction cost view of state competition that they appear to be advancing. If Delaware passed corporate laws that systematically favor lawyers to the detriment of firms on a large scale, it would lose its chartering business to another state whose lawyers were not as avaricious. Delaware maintains its position by mutual cooperation with, and not by exploitation of, firms. This is not to say that lawyers do not profit in Delaware. While lawyers are actively and intimately involved in Delaware's profitable chartering business, their participation provides no clear-cut insight concerning whether it benefits managers at the shareholders' expense. The important question, which Macey and Miller do not address, is how any rents are divided between Delaware, the bar, and firms.

40 The term is from Williamson, Credible Commitments: Using Hostages to Support Exchange, 73 Am. Econ. Rev. 519, 528 (1983).

41 Nevada, one of two states to experience a net immigration of corporations in the period 1960-1980, Romano, supra note 1 , at 246 , has sought to compete for corporate charters. It has been styled the "Delaware of the West," yet it has failed in its quest for a commanding share of the market. 
have to agree to move to it in concert. But there is no incentive for corporations to move to another state so long as Delaware continues to cooperate, and there are powerful incentives for Delaware to continue to do so.

\section{Takeover Statutes: ANomaly Or Exemplar?}

More than most provisions in corporation codes that are the technical terrain upon which the state competition debate is fought, state takeover statutes are a source of substantial controversy. The statutes were enacted in two waves. The first generation statutes, which spread rapidly across states in the 1970's, directly regulated tender offers by establishing waiting periods and administrative hearing requirements for bids for target firms that often had dubious jurisdictional contacts with the legislating state. After the Supreme Court held in 1982, in Edgar v. MITE Corp. ${ }^{42}$ that Illinois' statute burdened interstate commerce, new statutes with more plausible jurisdictional bases were devised.

The new statutes have three major forms: (1) control share acquisition statutes that require acquisitions of stock that constitute control, or the voting rights of such shares, to be approved by a majority vote of disinterested shareholders, ${ }^{43}$ (2) fair price statutes that require either a supermajority shareholder vote, disinterested board approval, or payment of a fair price for the second step of a two-tier acquisition, ${ }^{44}$ and (3) redemption rights statutes that give all shareholders cash redemption rights against any acquirer of at least thirty percent of the firm's stock. ${ }^{45}$ The fair price provision is the most popular of the three, having been enacted by fourteen of the twenty-one states to adopt second generation statutes. ${ }^{46}$ All three types of takeover statutes can raise the price of an acquisition, although unlike the first

42457 U.S. 624 (1982).

43 E.g., Ohio Rev. Code Ann. $\S 1701.831$ (Anderson 1985). Control share acquisition statutes have recently been held unconstitutional in several states. E.g., Fleet Aerospace Corp. v. Holderman, 796 F.2d 135 (6th Cir. 1986); Dynamics Corp. of Am. v. CTS Corp., 794 F.2d 250 (7th Cir. 1986), appeal granted, 107 S. Ct. 258 (1986), Terry v. Yamashita, 643 F. Supp. 161 (D. Ha. 1986).

44 E.g., Md. Corps. \& Ass'ns Code Ann. § 3-602 (1985). New York recently passed a more restrictive fair price statute that bans a second-step combination for five years after the first step, with limited exceptions. N.Y. Bus. Corp. Law $\$ 912$ (McKinney 1986). Its version appears to have replaced Maryland's as the model for states adopting fair price provisions. See, e.g., 1986 N.J. Sess. Laws Serv. ch. 74 (West).

45 E.g., 15 Pa. Cons. Stat. Ann. $\S 1910$ (Purdon Supp. 1986).

46 Romano, The Political Economy of Takeover Statutes, 73 Va. L. Rev. 111, 117-18 (1987). Only three states adopted a redemption rights provision and six chose control share acquisition statutes, of which two also enacted a fair price provision. For a discussion of why the fair price statute is the most popular, see id. at 117-20, 168-70. 
generation statutes, they codify tactics that firms could undertake by self-help through charter provisions and permit firms to opt out of the legislation's coverage. Their potential to discourage unfriendly acquisitions is, of course, what gives them bite, and, correspondingly, what makes them controversial.

Takeover statutes are of particular interest because they generate a puzzle for the state competition literature. Some commentators who contend that state competition produces laws that benefit shareholders have also maintained that mechanisms which facilitate management's efforts to thwart hostile bids, such as the actions codified by takeover statutes, are not in the shareholders' interest and should be banned. ${ }^{47}$ The difficulty for this position is that many firms choose their incorporation state to facilitate defensive maneuvering against takeovers. To be consistent, it would seem that the commentators must argue either that state competition is managerialist, or that defensive tactics are beneficial to shareholders. ${ }^{48}$

\section{A. The Politics of a Takeover Statute}

I set out to explore this apparent inconsistency in the literature concerning the effects on shareholder welfare of state competition and takeover defensive tactics by examining the politics behind the adoption of a second generation takeover statute. ${ }^{49} \mathrm{My}$ initial hypothesis, which was sparked by newspaper accounts, was that corporation code provisions might be differentiated as value-maximizing or managerialist, by who lobbied for their passage. In particular, if takeover laws were supported by a coalition of labor, local community leaders, and managers, it would support a managerialist explanation. Namely, managers would be better positioned to have enacted a law adverse to shareholders' interests when they could appeal for support to a broadbased constituency that had no particular interest in the everyday technicalities of corporation codes. I expected to find that takeover

47 E.g., Easterbrook, supra note 14, at 35 (state competition benefits shareholders); Fischel, The "Race to the Bottom" Revisited: Reflections on Recent Developments in Delaware's Corporation Law, $76 \mathrm{Nw}$. Univ. L. Rev. 913, 943-44 (1982) (same); Easterbrook \& Fischel, The Proper Role of a Target's Management in Responding to a Tender Offer, 94 Harv. L. Rev. 1161, 1165-82 (1981) (defensive tactics harm shareholders).

48 Ralph Winter distinguished state takeover laws from state competition over corporation codes because of takeover laws' extraterritorial effect-the first generation statutes applied to more than domestically incorporated firms. Winter, supra note 2 , at 268 . He maintained that this enabled the states to restrain competition for charters. Id. at 287-89. The second generation statutes, however, have a narrower jurisdiction and thereby lack the external effects with which he was concerned, for they apply only to domestically incorporated firms. Therefore, they cannot be so readily differentiated from other corporation laws.

49 The discussion that follows is from Romano, supra note 46, at 122-41. 
laws would be aberrational in their politics and, hence, sharply distinguishable from other provisions in corporation codes.

The hunch was wrong. In Connecticut, the passage of a fair price statute was of moment only to the business community. A major corporation in the state promoted the bill with the aid of a trade group similar to a state chamber of commerce. ${ }^{50}$ The only other group interested in the legislation was the executive committee of the corporate law section of the state bar association. The bar group opposed the statute, largely on procedural grounds; they had not been consulted and thought that such a statute should be scrutinized more carefully before enactment. ${ }^{51}$

Apart from the statute's quirky procedural status and consequent bar opposition, the experiences of other states are very similar to that of Connecticut: The only groups who are active in the enactment of second generation takeover statutes are business organizations and the bar. The statutes proceed through state legislatures at an extraordinarily rapid pace, with virtually unanimous bipartisan support, at the behest of the local business community and, most frequently, one concerned firm. This data supports what I term a putting-out-fires explanation of the enactment of takeover legislation, in which legislators simply react to a constituent's immediate concrete demands. To mitigate the problem of sampling error from relying on a case study, I also performed several statistical analyses to see which explanation-the coalition or the putting-out-fires explanation-best predicts which states adopt second generation statutes. Regressions including predictor variables that represented both theses, as well as economic variables indicating a state's prosperity, were estimated. But the results were inconclusive; the estimations offered some support for both explanations. ${ }^{52}$ I prefer the putting-out-fires explanation

so There was no opposition within the business community to the firm's proposal: The number of firms affected by the statute was small-a substantial number of the publicly traded firms had similar provisions in their charters and there are few acquiring companies in Connecticut. Moreover, the statute would matter to those acquirers only if they wanted to acquire other Connecticut firms.

51 Unlike the enactment of most other Connecticut corporate law provisions, the corporate bar was not consulted about the fair price statute and learned of it only after it was about to be approved by the state senate. The limited opportunity for involvement by the corporate bar in the legislation was connected to the peculiar procedural posture of the bill-having missed or waited until after the session's filing deadline, the fair price statute's sponsors had it attached as an amendment to an inconsequential bill providing for changes in corporate names. This procedure made it possible to bypass the requirement of a public hearing on the fair price statute. Romano, supra note 46 , at $122-28$.

52 The estimated equations were significant, explaining approximately $40 \%$ of the variation across the states of statute adoption, and having a statute was positively related to union membership and negatively related to the presence of domestic hostile bidder firms. Id. at 142-45. 
to the coalition hypothesis because it is supported by both anecdotal accounts and statistical data.

\section{B. When Should We Question Takeover Statutes?}

While the micro explanation of the political process identified the parties involved in the legislation, it did not provide much evidence for resolving the issue motivating the study: Whom do takeover statutes benefit? I therefore returned to first principles by trying to determine when shareholders would voluntarily adopt as a charter provision the requirements that the second generation statutes codify, for if we had a plausible explanation of which firms voluntarily adopt shark repellent amendments, we would be better able to assess how legislation incorporating such provisions impacts on firms, and whether managers promoting the statutes were acting in their shareholders' interest.

To study the incentive effects of the different provisions that the statutes codify, I examined the shareholder's decision problem in the takeover context-whether or not to tender-using a decision tree analysis that incorporates the findings of empirical research on takeovers. ${ }^{53}$ The analysis indicates under what conditions the provisions encourage shareholders not to tender their shares in the hope of receiving a higher price later. I then add to the analysis two important institutional details which aid in explaining why not all firms adopt shark repellent amendments: the typical multistage techniques bidders employ to obtain control, and the systematic differences across investors in information costs. The confluence of these factors creates a disproportionate sharing of takeover premiums in multistage offers across shareholders, with better-informed investors typically receiving the greater share. In the takeover situation, therefore, in contrast with the norm for corporate law, shareholders' interests may differ

53 The discussion that follows summarizes the conclusions in id. at 145-87. The analysis suggested why fair price provisions are more popular in charters and statutes than are control share acquisition or redemption rights rules. The latter two statutes consist of separate features that are combined in a fair price provision, supermajority approval, and equal premium payments, respectively. These statutes thus offer acquiring firms fewer options for the structuring of an acquisitive transaction than does a fair price statute. As a result, a fair price statute introduces fewer barriers to an acquisition. In addition, target shareholders' decisions to tender or not vary under the three takeover rules, such that only under a fair price regime is there a decision strategy in which the investor sometimes tenders and sometimes does not. These two factors suggest that shareholders approving shark repellent amendments could be rationally trading off a decrease in the probability of receiving an initial bid against an increase in the certainty of receiving an equal share of the bid premium. For the most frequently chosen tactic, a fair price provision, has the smallest impact on the likelihood of initial bids while at the same time, by providing an incentive to not tender in some cases, retains the possibility of receiving a higher premium. 
markedly. Consequently, views on the welfare-enhancing properties of shark repellent provisions may not be uniform across the commonstock class. In particular, because provisions such as a fair price requirement enable small investors to realize information cost savings by equalizing bid prices, small shareholders should tend to favor the adoption of such provisions while large institutional and individual investors, whose costs in obtaining information are lower and enable them to benefit from a disproportionate premium structure, should not. A firm's voluntary adoption of an antitakeover provision would correspondingly be dependent upon its ownership concentration. ${ }^{54}$

The corollary of an ownership-composition explanation of shark repellent amendments is that the impact of a statute will differ across firms, and, accordingly, can become quite problematic. For example, it could be a means for managers to circumvent shareholders where a favorable charter amendment vote would be doubtful. Given that management can place a proposal on the agenda with less difficulty than can a shareholder, this troubling possibility could be mitigated by opt-in rather than opt-out regimes. ${ }^{55}$ But opting in also has disadvantages: Because a vote is still required, it negates much of the transaction cost savings of a statute for those corporations whose shareholders would approve a charter provision.

I sought to test whether ownership concentration would be an accurate predictor of firms with shark repellent amendments by comparing concentration measures for firms with and without fair price provisions. None of the differences were statistically significant. I also divided the firms in the sample by incorporation state, based on

\footnotetext{
54 Barry Baysinger and Henry Butler maintain that support for shark repellent provisions comes from shareholders who have special relations with firm management such that their shares would be worth less under new management and are worth more to them than the premium paid by an outsider. Baysinger \& Butler, Antitakeover Amendments, Managerial Entrenchment, and the Contractual Theory of the Corporation, 71 Va. L. Rev. 1257 (1985). They further contend that this stock relation, which they view as a transaction specific asset, is independent of the size of the holding. Id. at 1284-88. They do not connect their thesis concerning firms' choice of incorporation state, see supra text accompanying notes 18-25, and firms' adoption of shark repellent amendments, although the two choices are related because firms often choose their incorporation state to facilitate adopting such measures, as well as to be protected by a takeover statute. Even if we assume that the concept of transaction specific stock is sensible (and I have serious doubts about this that cannot be pursued in this paper without going off on an unrelated tangent), an analysis of the effects of the most popular shark repellent amendments indicates the problem with the thesis: These provisions do not unambiguously favor shareholders with special relations to managers, unless they are the managers themselves. See Romano, supra note 46, at 170-87. Moreover, if certain shareholders have special relations with management that were beneficial to all shareholders of the firm, then we need an explanation for why those relations would not be continued by new management.

55 Only a few states have opt-in rather than opt-out provisions. E.g., Ga. Code Ann. § 142-235(a) (Supp. 1986); Minn. Stat. Ann. § 302A.167 (West Supp. 1987).
} 
whether or not they had a second generation statute, and compared the concentration levels for those with and without fair price provisions within the subgroups separately. The concentration ratios differed significantly across the states, with the concentration ratios being lower in states with second generation statutes. ${ }^{56}$ This appears to support a transaction-cost-reducing view of the statutes-states that have enacted the legislation have more firms with diffuse ownership, which are the firms, under my conjecture, whose shareholders would approve such provisions. But in an equal-sized sample, the difference was not significant. In addition, there is anecdotal evidence in support of the opposite proposition: The firm that promoted the Connecticut legislation has a relatively high concentration ratio which, in keeping with the ownership composition thesis, suggests that its management might have had difficulty obtaining shareholder approval. ${ }^{57}$ These two pieces of information are not, however, necessarily inconsistent: Takeover statutes may be promoted by managers who fear a negative shareholder vote, while the rest of the local business community does not object to the proposal because their shareholders would voluntarily adopt a provision.

The impact of takeover statutes remains, then, a troubling, open question, as some firms can use a statute to undermine the shareholder sovereignty on which corporation law is premised. In this sense, the Connecticut experience suggests that state chartering may not always be an unmitigated good. Yet it also implies a positive assessment of Delaware's role in the corporate charter market. Delaware has yet to enact a second generation statute. In fact, it was slow to enact a first generation statute, and the one it adopted was not as hostile to bids as other states' versions because there was no hearing requirement and firms could opt out of its coverage. This is not coincidental: Delaware is better able to resist political pressure for takeover laws because of the large number of incorporated firms, which

56 Romano, supra note 46 , at 179 . As a conceptual matter, concentration measures have no strict implication for the enactment of statutes because firms with diffuse ownership, which could presumably adopt such provisions on their own, might want a law to reduce drafting costs, yet, managers of firms with concentrated ownership might also want a law because they cannot employ voluntary solutions. If enactment of takeover statutes evinces a permissive state, then this data supports Baysinger and Butler's pairing of more diffusely owned firms and lax jurisdictions, see supra text accompanying notes 18-25. But when I used a random sample with an equal number of firms in each subset to provide a more powerful test of the difference of means, as Baysinger and Butler used for their analysis, the difference in shareholder concentration across the states was not significant.

57 The sponsoring firm was also doing poorly at the time, and shortly after the statute's passage there was a change in top management. 
includes both acquirers and targets. ${ }^{58}$ Delaware legislators have to be responsive to a corporate constituency whose interests are varied and conflicting. In addition, other interested parties who oppose restricting takeovers, such as financial intermediaries, would find it more worthwhile to lobby in Delaware than in other states because its statute would have a greater impact on acquisitions, as it would apply to so many firms. Consequently, it is unlikely that any one firm could have the political clout in Delaware that individual firms display in other states like Connecticut, in having second generation statutes enacted. ${ }^{59}$ As a result, we can expect a different political equilibrium in Delaware than in other states when it comes to takeover defenses, in which target firms rely on self-help and shareholder approval rather than on a mandated statutory solution.

\section{Event Studies as ARbiters of the Debate}

The debate over the efficacy of state corporation codes essentially boils down to an empirically testable hypothesis: whether managers or shareholders benefit from the market for corporate charters. If we could identify the beneficiaries, then fashioning a political consensus regarding the optimal level of government regulation would be straightforward. ${ }^{6}$ The best available means of generating information bearing on this issue is to examine the impact of reincorporations on stock prices, for a change in equity value conveys investors' assessment of the event's ${ }^{61}$ expected effect on shareholder wealth. A stock

58 The second generation statutes create an externality, though of a different sort described by Winter's analysis of first generation statutes, see supra note 48 . States like Connecticut may be benefitting local target firms at the expense of nonresident acquiring firms.

59 There is very little research, although there is need for some, on the modern political history of Delaware. Some have contended that the DuPont family and their corporation run the state, see J. Phelan \& R. Pozen, The Company State 113-32 (1973), but that claim is disputed, and viewed with skepticism by local historians, see, e.g., C. Hoffecker, Corporate Capital: Wilmington in the Twentieth Century 260-61 (1983).

60 Of course, the issue may be resolvable only in theory: Limitations of data and statistical techniques may render an answer impossible. Moreover, an analyst's priors will affect the weight he or she attributes to empirical findings, which may result in an exceedingly slow updating of beliefs that hinders the development of a consensus on policy.

61 An "event" can be technically defined as a change in the information set about firms from which price expectations are formed. An event's effect can be isolated from the effects of other factors that influence the market by standard econometric techniques. The regressions typically employ a version of the capital asset pricing model of security valuation. That model asserts that there is a positive linear relation between an asset's risk and return, and in particular, that the risk premium varies in direct proportion to the stock's sensitivity to market movements, which is referred to as the stock's beta. Betas estimated from stock prices in a period prior to the event are used to predict stock prices at the time of the event. The regression residuals, which are the difference between the predicted prices and observed prices, measure abnormal returns that can be attributed to the event. Event studies are therefore tests of semi- 
price increase upon a firm's reincorporation would mean that investors expect the change in incorporation state to increase the firm's future cash flows, and from this it could be concluded that shareholders benefit from a move. Similarly, a decline in stock price would indicate the anticipation that shareholder welfare will be diminished by the move and confirm the managerialist position.

Several event studies have been performed that bear on the state competition debate. Researchers have addressed the issue directly by investigating the impact of reincorporating, and indirectly by looking at the effect of state court decisions and state takeover laws. The results are summarized in Table One. None of the studies support the managerialist position, for none found a negative effect on stock price. Rather, to the extent they can be used to buttress any position, it is the value-maximizing view associated with Ralph Winter.

\section{A. Event Studies on State Competition}

Peter Dodd and Richard Leftwich, in the first empirical study concerning state competition, found statistically significant positive abnormal returns to the stock of reincorporating firms over the twoyear period preceding the reincorporation. ${ }^{62}$ The returns around the event date were not, however, significant. While this finding undermines Cary's position, it is difficult to assert that it bolsters Winter's view, because the period of abnormal returns is so far before the announcement of the move that it is possible the abnormal returns are due to some other factor affecting the firms.

I sought to refine the Dodd and Leftwich study by partitioning the portfolio of reincorporating firms according to the reasons for which the reincorporation was undertaken, and by using daily rather than monthly stock price data. ${ }^{63} \mathrm{I}$ found that firms which reincorpo-

strong-form market efficiency-the hypothesis that all publicly available information is reflected in stock prices and changes in the information set are instantaneously reflected in price adjustments. To ensure that only the effect of the event of interest is being measured, a portfolio of firms that have experienced the event is created and the average residual of the group is studied. In addition, when there is uncertainty over the precise date of the event-that is, the day on which the information that is conveyed by the event became publicly available in the market-the average residuals are cumulated over an interval in event time and the relevant datum is the cumulative abnormal return. When event dates are well-specified, the methodology is very accurate. See Brown \& Warner, Using Daily Stock Returns: The Case of Event Studies, 14 J. Fin. Econ. 3 (1985) [hereinafter Brown \& Warner II]; Brown \& Warner, Measuring Security Price Performance, 8 J. Fin. Econ. 205 (1980).

62 Dodd \& Leftwich, The Market for Corporate Charters: "Unhealthy Competition" versus Federal Regulation, 53 J. Bus. 259, 274-75 (1980).

63 Romano, supra note 1 , at $265-73$. Tests relying on daily data are more accurate than those using monthly data, as daily data allow for more precise identification of events, assuming the event date is accurately specified. Brown \& Warner II, supra note 61 , at 12 . 
Table One. Research Findings on State Competition

Study $\underline{\text { Type }} \underline{\text { Results }}$

1. Dodd and Leftwich Event study of (1980) reincorporation

2. Jarrell and Bradley (1980)

3. Romano (1985)

4. Guerin-Calvert, McGuckin and Warren-Boulton (1986)

5. Weiss and White (1986)

6. Romano (1987)
First generation takeover statutes (event $=$ acquisition)

Event study of reincorporation, firms grouped by motive for move

First generation takeover statutes (event $=$ acquisition; other techniques also employed)

Event study of Delaware court decisions

Event study of second No effect generation takeover statutes
Positive cumulative average residuals, 2 years before event Premium higher, more shares acquired, in states with statutes Positive cumulative average residuals, $1-10$ days around event, for merger and aggregate portfolios Premium higher, more multiple bids, in states with statutes

No effect

rated in order to embark on merger-and-acquisition programs, as well as the aggregate portfolio of reincorporating firms, experienced statistically significant positive abnormal returns on and around the event date. The signs of the cumulative average residuals for the other groups were also positive, although they were not significant. ${ }^{64}$ This finding creates further difficulty for the Cary thesis, and provides more clear-cut support for Winter's value-maximizing interpretation of state competition. Elliot Weiss and Lawrence White challenge my conclusion and assert that the abnormal returns are not due to reincorporating because they begin to accrue prior to the event date. ${ }^{65}$ Weiss and White are mistaken. Although, as I stated in that article, the positive revaluation of the firm's stock may be generated by the activity associated with the reincorporation rather than the

64 I had expected to find a negative effect on the stock of firms that had reincorporated for antitakeover purposes, but none could be detected. This provided further evidence of the inconsistency in some commentators' positions on state competition and takeover defensive tactics, see supra text accompanying note 47 , and spurred me to investigate the politics behind state takeover laws as a possible explanation.

65 See infra note 66. 
reincorporation itself, the rise in price that occurred in the months preceding the event date is almost surely caused by leakage concerning the plan to reincorporate and engage in the associated activities rather than any other unrelated events, because all firms that were the subject of any report in the Wall Street Journal in the two months preceding and one month following their event dates were excluded from the sample.

Weiss and White examined another theme in the literature to get at the crux of the state competition debate: Who is helped out by Delaware court decisions? ${ }^{66}$ They investigated the effect of seven Delaware opinions that they characterized as reversals or departures from existing corporate law rules. They hypothesized that if the decisions benefited shareholders, firms would experience abnormal positive returns, and if not, there would be negative returns. They found no statistically significant abnormal returns earned by Delaware firms, and the signs of the residuals were not consistent with any particular thesis. ${ }^{67}$

As a further test of the state competition debate, Weiss and White sought to explain the relative size of the cumulative average residuals for one of the decisions-Singer v. Magnavox Co. ${ }^{68}$-by examining the firms' likelihood of being taken over. They put forth two alternative scenarios: If the decision was detrimental to shareholders because it discouraged takeovers, companies that are more likely to be targets would have larger negative residuals, and if the decision was favorable to investors because it decreased the likelihood of an exploitative cash-out, companies that are more likely to be taken over would have larger positive residuals. This is their more interesting

66 E. Weiss \& L. White, Of Economics and Indeterminacy: A Study of Investors' Reactions to "Changes" in Corporate Law (draft October 14, 1986) (available at Cardozo Law Library).

67 Because Delaware firms make up a large segment of the market, and thus may invalidate the abnormal returns methodology, they also examined the effects of the decisions on a portfolio of non-Delaware firms. Again, the results were largely statistically insignificant, and the signs of the residuals were not always the opposite of the signs of the residuals of the Delaware firms, as they had hypothesized. Id. at 47-58. I do not believe, however, that this technique deals adequately with the problem. To the extent that state competition tends to produce uniformity in corporation codes, then corporate law rules embodied in court decisions will be contributing to systematic risk and not unsystematic risk, and therefore will not be picked up as an abnormal return for either set of firms. Weiss and White recognize this possibility as an interpretation of their finding of no statistical significance but then reject it as unrealistic without any convincing reason. Id. at 64.

68380 A.2d 969 (Del. 1977). The decision affected the rights of dissenters in cash-out mergers. Because we do not have very good theories for predicting which firms will become targets, an interesting ad hoc test would be to examine the residuals of firms that subsequently were acquired. 
test because most of the judicial opinions are of concern only to a subset of firms-potential targets-and hence, in a randomly constructed portfolio of Delaware firms, only some of the firms would fit this category. Any effect of the event on those firms could be overwhelmed by the insignificant effect of the event on the aggregated portfolio. The regression failed, however, to explain much of the variation in the residuals: Only one of the characteristics of targets that they identified-firm growth-was significant.

Weiss and White conclude from the failure to find abnormal returns and the lack of explanatory power of their regression of the residuals on target characteristics, that investors do not believe that changes in corporate law affect stock value and that, correspondingly, investors are not concerned about differences in statutory regimes. As a result, they maintain that there is no state competition to speak of. Their study makes an important contribution to our understanding of the impact of certain court decisions, but the implications they derive for the state competition thesis from their data are questionable. In the first place, a plausible alternative interpretation of the data is that investors anticipate Delaware court decisions better than do researchers. ${ }^{69}$ Indeed, they provide no persuasive evidence that the corporate bar was taken by complete surprise by the decisions. A complementary explanation is that it is likely that shareholders anticipate that the state legislature will reverse any undesirable decision. For example, Delaware recently revised its code to allow firms to limit outside directors' liability. ${ }^{70}$ This move is presumably a reaction to the Delaware Supreme Court's decision in Smith v. Van Gorkom,$^{71}$ which held outside directors liable for accepting too hastily an acquisitive offer. In addition, given the complexity of corporate acquisitions, many of the decisions in the study could have offsetting positive and negative effects on shareholder welfare, which could result in insignificant residuals. Weiss and White's uncertainty as to the impact of Singer and the fact that a firm that is the acquirer in one transaction may be the target in another, are instances of the complexity of the effects that need to be sorted out.

Although some participants in the state competition debate have

69 If we adopt a strong rational expectations view of the market, then we would also not predict any reaction to court decisions because, as investors expect all decisions to have only welfare enhancing (or diminishing) effects, all of the value of those decisions would be impounded in the stock price at the time of incorporation or reincorporation in Delaware.

70 Act of June 18, 1986, ch. 289, 65 Del. Laws $\S \S 1,2$ (codified at Del. Code Ann. tit. 8, $\S 102(\mathrm{~b})(7)(1987))$.

71488 A.2d 858 (Del. 1985). For a critique of the decision, see Fischel, The Business Judgment Rule and the Trans Union Case, 40 Bus. Law. 1437 (1985). 
emphasized the role of the Delaware judiciary in furthering the state's market position while disputing who has benefited from state law doctrine, ${ }^{72}$ there is another important role for courts, with sharply different implications. One factor that transaction cost economics emphasizes is that reducing uncertainty reduces the cost of doing business. Hence, certainty concerning the structuring of a transaction is valuable. One of the benefits stressed by firms reincorporating in Delaware was its pool of precedents, and the corresponding ability to receive opinion letters on contemplated transactions quickly. In this regard, the substantive content of the rule is less important than having a rule. A rule defines the rights of the parties, enabling them to bargain around it if they so wish, and provides guidance as to how a transaction should be structured if liability is to be avoided. This feature permeates corporate law: corporation codes are enabling statutes that set presumptions to govern specific issues and allow firms to tailor their internal organization around the rule. Indeed, the costs of particular rules could be offset by the benefits of having a rule around which future transactions can be planned. Thus, from the transaction cost perspective, it is not surprising that the market did not react to the decisions in any systematic way, and the statistical insignificance would not indicate that being subject to Delaware's legal regime is detrimental to shareholders.

In addition, Weiss and White's findings must be interpreted with caution. Besides the obvious fact that, given the standard understanding of statistical techniques, a failure to find significance does not provide evidence supporting the alternative hypothesis (such as the Cary position that Weiss and White prefer to the Winter position), their conclusion is built upon a description of the evolution of corporate law rules produced by court decisions over time that is inconsistent with the methodology they applied. Courts are depicted as engaging in a balancing process that continually adjusts and reconciles the interests of shareholders and managers, in which no one decision can be evaluated separately. Such a story is most in keeping with an explanation that Weiss and White reject, that the event study methodology is inappropriate for determining the effect of court decisions, rather than the position that there is no such thing as state competition. If judicial decisionmaking is the perpetual adjustment process they de-

72 Compare Cary, supra note 3, at 670 (Delaware courts create a "favorable climate" for management to further its own interests at the expense of shareholders' interests) and Fischel, supra note 72 (criticizing certain Delaware decisions for decreasing firm value) with Fischel, supra note 47 , at 943 (shareholders benefit by recent Delaware decisions) and Winter, supra note 2, at 260-61 (decisions which seem to favor management are not necessarily unfair to shareholders). 
scribe, it does not consist of discrete events. ${ }^{73}$ Event studies do notand cannot-evaluate the effects of evolutionary processes. The methodology presupposes information of a lump-sum nature that is introduced in the market instantaneously with a single event, and its accuracy is a function of the correct specification of an event date. Thus, given their characterization of the judicial process, their study can provide no information on the crucial issue of who benefits from state competition, nor can they draw any conclusion concerning the process of, or investors' attitudes toward, state competition.

\section{B. Studies on the Effect of Takeover Statutes}

Research on first generation takeover statutes has produced uniform findings, although only one of the two empirical studies on this topic sought to relate the findings to the state competition debate. Gregg Jarrell and Michael Bradley, and Margaret Guerin-Calvert, Robert McGuckin, and Frederick Warren-Boulton (the "Economic Analysis Group"), using both cumulative average residual techniques to estimate bid premiums and actual bid prices, found that the premiums received by target firms in states with takeover statutes were significantly higher than those received by firms in states without regulation. ${ }^{74}$ There is variation in the studies' findings on whether state regulation reduces the number of acquisitions. The Economic Analysis Group found no clear evidence that the proportion of successful takeovers declined as a result of regulation. In contrast, Jarrell and Bradley found that the relative frequency of successful cash tender offers for firms in states with statutes declined after the legislation was enacted. Of course, none of these results resolve the state competition debate. At best, they point to a possible trade off of premium size against initiation of bids, which makes it difficult to decipher whether shareholders are losers or gainers under these laws.

The Economic Analysis Group did, however, relate their re-

73 This is also true if legislatures systematically overturn judicial opinions.

74 Jarrell \& Bradley, The Economic Effects of Federal and State Regulations of Cash Tender Offers, 23 J.L. \& Econ. 371 (1980); M. Guerin-Calvert, R. McGuckin \& F. WarrenBoulton, State and Federal Regulation in the Market for Corporate Control, Economic Analysis Group Discussion Paper 86-4, Antitrust Div., Justice Dep't (Jan. 21, 1986) [hereinafter Economic Analysis Group]. Jarrell and Bradley also found that acquirers of firms in states with statutes purchased a higher percentage of shares, and the Economic Analysis Group found that targets in states with statutes were more frequently the subject of multiple bids. In this regard, it would be useful to remove the multiple-bid firms from the sample to see how much of the difference in premiums across states is due to actual auctions rather than the effect of statutes alone. However, it may be difficult to disentangle the effects of statutes and auctions, because bidders, knowing that the statutes make auctions more probable, may raise their initial bids to make competition less likely. 
search directly to the incorporation debate. Jarrell and Bradley appear to have restricted their identification of regulated firms to those whose incorporation state had a takeover statute, thereby possibly misclassifying some targets whose bids were, in fact, subject to regulation. The Economic Analysis Group included and distinguished targets by their susceptibility to both place of business and charter regulation. They found that when they partitioned their sample of regulated targets by type of jurisdiction, the dummy variable for jurisdictional type was significant. They had hypothesized that this would be so, because they believed that regulation based on a firm's physical location more clearly constitutes a negative externality than regulation by incorporation state, since moving assets is more costly than moving a charter. They concluded that place-of-business regulation might be the most important component of the significant effects of state regulation on bid premiums in the estimations in which no jurisdictional variable was included.

Second generation statutes are only of the incorporation state jurisdictional variety, and thus, examination of their effect might shed more light on the Economic Analysis Group's work. I studied the effect on stock prices of each type of second generation statute, rather than their impact on bid premiums. ${ }^{75}$ Because most second generation statutes are passed quickly, with little debate and virtual unanimity, they are better suited than most laws for an event study in which pinpointing the event date is crucial to the power of the statistical tests. The statutes I examined were those adopted by Connecticut (fair price provision); Missouri (control share acquisition statute); and Pennsylvania (redemption rights provision). All of these states enacted the legislation within a month or so after their bills' introduction, and are thus good candidates for an event study. ${ }^{76}$

No effects were discernible in any of the regressions: The average residuals were not significant on or near the event date, and the cumulative average residuals were not significant in any of several intervals around the event date, revealed no nice pattern, and were of small negative magnitude. ${ }^{77}$ Of course, since not all firms are potential

75 Romano, supra note 46 , at $181-86$.

76 I chose Connecticut for the study of a fair price statute, even though its small population of publicly traded firms reduces the power of the test, because, in addition to my ability to date precisely its enactment, my knowledge of the legislative history could provide a useful interpretative gloss on any results. Pennsylvania has the benefit of having a large pool of firms as well as a short time from introduction to enactment, and Missouri had the shortest time from introduction to passage of the states with control share acquisition statutes for which accurate dates were available, although like Connecticut, it has too small a number of firms to provide a powerful test.

77 The cumulative average residuals of Missouri firms that did not have fair price charter 
takeover targets, not all firms should be expected to experience abnormal returns upon the enactment of these statutes. This seriously weakens the power of the tests, because the aggregate portfolio could be burying the impact of the legislation on the unidentifiable subset of future target firms (although presumably the market also cannot predict in advance which firms are future targets). An ad hoc examination to see if this was a factor, by looking at the residuals of firms that subsequently turned out to be targets, did not help. One Connecticut firm, Scovill, Inc., was involved in a takeover fight shortly after the Connecticut statute's enactment. ${ }^{78}$ However, Scovill's abnormal performance was not greater than that of other Connecticut firms. In addition, the returns of the proponent of the Connecticut legislation were insignificantly negative.

In sum, the financial research on takeover statutes does not provide much information on the state competition debate. It cements the intuition that these statutes, like most defensive tactics, will increase the premiums target shareholders receive, possibly at the cost of a reduction in the aggregate number of bids. Such a trade-off does not indicate whether shareholders, managers, both, or neither, are better off. To be sure, the event studies on reincorporation, which go directly to that question, offer far greater support to the Winter position than to the Cary position-there is no evidence of negative returns to migrating firms (or to firms operating under Delaware law) and some evidence of positive returns. But studies of specific statutes' impact are even more inconclusive and are subject to substantial methodological difficulties, given the limitations on obtaining precise event dates for legislation. What we can say with some degree of confidence is that reincorporation produces abnormal positive returns for some firms (those engaging in certain transactions), and for the rest it is a zero net present value transaction. ${ }^{79}$

provisions at the time the statute was enacted show an upward trend after the bill passed the state Senate (t-statistic 1.2), in contrast to the residuals of the firms that already had such provisions. In addition, in all the regressions, some average residuals were significant approximately one week after the event dates, but trying to draw conclusions from such data would be equivalent to reading tea leaves.

78 While Scovill's management was not involved in the drafting or passage of the legislation, it hoped it would be protected by the law. In the end, the statute did not affect the bid because it was an any-or-all offer.

79 Romano, supra note 1, at 272-73. Macey and Miller misuse this conclusion in their paper when they assert that it was grounded in a survey of reincorporating firms and not the event study. Macey \& Miller, supra note 34, at 16 . They are also mistaken in asserting that the survey produced biased information because of self-serving answers by managers. The explanations for reincorporations provided by respondents were independently verified by public sources of information, wherever available. In addition, the respondents were not only 


\section{Stability and Optimality in State Competition: A MARKOV MODEL}

One way to explore the dynamics of state competition is to use a probabilistic model known as a Markov process. ${ }^{80}$ A system following a Markov process embodies the intuition motivating the state competition debate because its evolution through time can be conceptualized as propelled by the winner of a series of independent competing forces. The forces can be arrayed in a matrix that generates the process and enables us to describe its likely progression. From such a matrix, we can obtain the process' stationary or limiting probability distribution, which indicates the long-run tendency of the system to be in a specific state.

Such a model abstracts away a legislature's ability to control the competitive process, and is analogous to an invisible hand. It is in the spirit of the Hayekian view of the benefits of decentralization-the spontaneous aggregation of information. It thus provides a rough baseline approximation for assessing the optimality and stability of the corporate charter market. It is a stylized story with the advantage of a model, that of making assumptions explicit and of assessing effects of small changes in variables in the system. The model's benefits are also its limitation: The dynamic properties of Markov processes are definitional, such that if a process is Markov, it follows specific rules. This means that an important initial focus of analysis is whether such a process is an appropriate characterization of state competition. Accordingly, I first detail the assumptions for modeling state competition as a Markov process, and thereafter consider several simple simulations for illustrating what the long-run tendency of the system could be.

\section{A. Defining the Process as Markov}

The system we are modeling is the array of corporation laws of the fifty states. To avoid confusion, I will refer to the real states as jurisdictions and to Markov system states as states. A "state" of a

managers, but also legal counsel, both inhouse and outside, and the responses did not differ systematically with the identity of the respondent.

80 Robert Cooter and Lewis Kornhauser used a Markov process in their contribution to the debate on the efficiency of the common law. Cooter \& Kornhauser, Can Litigation Improve the Law Without the Help of Judges?, 9 J. Legal Stud. 139 (1980). Their article inspired this discussion. Additional use of such models can be found in R. Nelson \& S. Winter, An Evolutionary Theory of Economic Change (1982). To capture the notion of jurisdictional competition, I use a continuous-time Markov process, which is a Markov chain subordinated to a Poisson process, rather than the discrete-time Markov chain that Cooter and Kornhauser use. 
Markov system is the particular constellation of laws enacted in the jurisdictions. A Markov process is a way of describing how a system moves across its various states. For example, let us assume that there are only three jurisdictions, $A, B$, and $C$, and two laws, 1 and 2. Table Two lists the possible states of such a simple system. If, for instance, the current state is: $A$ has corporation law $1, B$ has corporation law 2, and $C$ has neither law, this is summarized in the table as the state numbered nineteen. I will continue to use the word state, rather than jurisdiction, to refer to real states when using the phrase "state competition."

The information concerning a system's dynamics can be described as a matrix; the matrix has rows and columns equal to the total number of possible states (64 in our example). In a Markov process, a system stays in a state for a random period of time and then moves to another state, according to stable transitional probabilities. State competition is depicted as a process that moves stochastically from one set of laws in the jurisdictions to another set. To continue our earlier example, $C$ might decide to enact law 2 . In this new state, $A$ has law 1, $B$ has law 2, and $C$ has law 2. In Table Two, this change is a move from the state numbered nineteen to the state numbered fifty-one. If we call the original state state $i$, and this new state state $j$, the matrix entry $(i, j)$ indicates the force by which the system moves from state $i$ to state $j$. From this entry, we can derive a transitional probability, $Q_{i j}$, that describes the likelihood of starting at $i$ and moving to $j$, and time $\lambda(i)$, the actual staying time, or sojourn, of the system in $i$ before it moves. Remaining in a state, which is described by the entry $(i, i)$, may also be a movement of the process.

Two assumptions are necessary to describe the model as Markov, which will enable us to use the mathematical properties of Markov processes to study the evolution of the system. A third assumption will be useful to explore the optimality of the system. The three assumptions are:

A.1: The number of states is finite.

A.2: Legislatures consider only the present set of laws and not their history in deciding to adopt or repeal a particular law. In other words, only the present state of the system is relevant for the future state.

A.3: There is always a possibility that a law may be adopted or repealed.

The first assumption of finite states is adopted primarily for 
mathematical convenience. ${ }^{81}$ It is neither inherently implausible nor technically important to warrant discussion.

The second assumption is crucial, for it is the defining characteristic of a Markov process-that the future is conditionally independent of the past, provided the present is known. This is not as controversial as it may appear. It does not mean that studying legislative intent or legislative history of a statute is irrelevant. Rather, it implies the plausible scenario that when a legislature is considering a change in its corporation code, the probability of the change occurring depends only on the legislators' knowledge of the current legal regime-its own laws and the laws of other jurisdictions at that time-and not on the history of when those laws came to be enacted. Unlike courts, whose decisions are said to be constrained by precedent, it is reasonable to posit that legislators approach each lawmaking session from their knowledge of present conditions and needs. For instance, legislators reintroduce bills that have failed in previous sessions, and laws that were adopted in one session are often modified in the very next session. ${ }^{82}$ Moreover, conventional wisdom supports this assumption in the constitutional maxim that one Congress cannot bind a future Congress.

This second assumption contains a further, perhaps more disputable, restriction on the legislative process: The probabilities of change are independent of time. This means that the likelihood of starting in state $i$ and moving to state $j$ (such as $C$ 's enactment of law 2 when $A$ has law $1, B$ has law 2 and $C$ originally has neither law) remains the same throughout time, whether it is May or September, 1986 or 1926 . More precisely, the transition probabilities depend only

81 If the state space of a Markov process is finite, then there are limiting probabilities that are unique so that we can speak of a stationary or steady state of the system in which, in the long run, it spends a fixed proportion of its time in each of the possible states. If the state space is infinite, then these limiting probabilities may not exist, although a solution can be obtained in terms of ratios of time spent in particular states. But even if the number of states is infinite, if the process is non-null, which my other assumptions provide, then there is a unique stationary distribution. E. Çinlar, Introduction to Stochastic Processes 264 (1975). A.1 is therefore technically not required to guarantee the uniqueness of a steady state. However, finiteness ensures certain regularities in the Markov process that exclude the occurrence of instantaneous states, which are states that the process jumps out of as soon as it enters them. Id. at 243-44. Such states make little sense in the legislative context, as the deliberation process takes time, and therefore, A.I is a useful assumption. I do not make any assumption concerning aperiodicity because in a continuous-time Markov process, periodicities disappear in the steady state.

82 See, e.g., 19 Sec. Reg. L. Rep. 84-85 [Jan. 1987] (BNA) (Sen. D'Amato introduced S. 227 , tender offer reform bill, identical to bill introduced in previous session). Connecticut's second generation takeover statute, which was enacted in the Spring of 1984, 1984 Conn. Acts 716, P.A. 84-431 (Reg. Sess.), was modified in the next session to repeal the exemption for firms that had an interested 10\% shareholder, 1985 Conn. Acts 384, P.A. 85-283 (Reg. Sess.) codified as amended at Conn. Gen. Stat. Ann. § 33-374(a) -374(c) (West Supp. 1986). 
upon the state in which the system is and not the time at which it is in the state. ${ }^{83}$ This would be a troublesome restriction if, for instance, legislators behave differently at election time, or if the probabilities of passage differ dramatically with the composition of the legislature. ${ }^{84}$

I believe, however, that the homogeneity restriction does not create serious difficulty in the corporate law context. First, one of the consistent features in the enactment of corporation laws, illustrated by the politics of Connecticut's second generation takeover statute, is the bipartisan, near unanimous, support for such provisions. ${ }^{85}$ Second, corporation laws are generally not a salient issue in election campaigns. Third, we can rely on the notion of a "critical election" to maintain that when new representatives take office the transition function does not change. Political scientists have theorized that on certain rare occasions, such as the election ushering in Franklin Roosevelt's New Deal, a critical political realignment of interests occurs and profoundly changes the course of history. ${ }^{86}$ Only after such an election would the probabilities of legislative responses to a given set of laws change. Thus, at a minimum for the extended periods of time in routine politics, a Markov process is a reasonable approximation for modeling state competition.

The third assumption affects results concerning the optimality of the system. The only means of ensuring that the system moves to and stays in the optimal state is to assign zero probability to the repeal of a value-maximizing law and a probability of one to the adoption of a value-maximizing law. This third assumption rules out such a guarantee. ${ }^{87}$ It can be analogized to an assumption of bounded rationality on the part of legislatures, that they do not always recognize a valuemaximizing law and they legislate by trial and error. Moreover, it captures an important institutional detail of corporate law: All jurisdictions have statutes reserving to themselves the power to alter any corporate law provision and to impose that change on firms that were

83 This is the requirement that the Markov process be time homogeneous. The transition function incorporates the time spent in a state before the process changes; the process is time independent in that the probabilities are unaffected by the sojourn time in the state and the time at which the state is entered.

84 If elections were not held at fixed intervals but occurred randomly, and therefore followed an exponential distribution, then the problem that the election process could disturb the time homogeneity requirement of a Markov chain would be avoided. Elections in parliamentary systems satisfy such a condition, as the prime minister calls the election.

85 See Romano, supra note 46 , at $128,138$.

86 W. Burnham, Critical Elections and the Mainsprings of American Politics (1970). The critical-election literature has serious theoretical problems since it is an ex post characterization of events, lacking predictive content.

87 More precisely, A.3 ensures that there is no absorbing state, which may be defined as a state from which the process never leaves. 
chartered under the previous law. ${ }^{88}$ The model of the process thereby adopted is a relatively weak form of the shareholder wealth-maximization branch of the state competition debate, which accords best with the empirical studies, for it can weight the transition probabilities to favor moves to more optimal states and disfavor moves in the opposite direction, yet it cannot rule out those reverse moves.

These three assumptions are sufficient to characterize competition as a Markov process and to attain the Markov property that there is a unique set of transition probabilities into which the process settles, which is independent of where it began. The trigger of change-the source of the motion of the process-is itself a random process that may depend on the other jurisdictions. There are at least three possible methods that spur a legislature to reconsider its legal regime, and all may stem from the existence of other jurisdictions: (1) corporate interests lobby the legislature to innovate or imitate by bringing its laws in line with those of other jurisdictions, as in the case of the Connecticut second generation takeover statute, (2) corporate capital leaves the jurisdiction as some firms reincorporate or as shareholders alter their portfolios and firm values decline, as suggested by the Cary and Winter hypotheses, and (3) legislators themselves innovate or keep abreast of developments in other jurisdictions and suggest trying proven or popular measures that they think will help solidify their political positions. I assume that the occurrence of any of these factors, which brings a law to the legislature's attention and calls into play the Markov transition probabilities, follows a random path. ${ }^{89}$

88 E.g., Del. Code Ann. tit. 8, $\$ 394$ (1984). See W. Cary \& M. Eisenberg, Cases and Materials on Corporations 147-48 (5th ed. 1980). These reservation statutes are typically incorporated into the firm's incorporation documents. E.g., Del. Code Ann. tit. 8, § 394 (1984) ("[The corporation law] and all amendments thereof shall be a part of the charter or certificate of incorporation of every corporation.").

89 For mathematical convenience, I assume that the random process that sets in motion the transition between states is independent of the destination state and memory-less, that is, the sojourn time follows a Poisson process. This means that the interarrival times, where an arrival is the time at which a legislature begins to consider a statutory change, are independent and identically exponentially distributed. The timing of the legislature's consideration of a reform is such that, knowing that the time elapsed since the last consideration of a law is $t$ units long does not alter the probability of the interval lasting another $s$ units of time. Although certain laws, such as budgets, are considered at fixed times of the year, it seems reasonable to treat the review of corporation laws as following such a random process. If the timing of legislative consideration is not exponentially distributed, the process could be modeled stochastically as a more general Markov renewal process. The added complexity in the calculations that would be necessary to relax the restriction on interarrival times would not, in my opinion, produce a commensurate gain in explanatory power. 
Table Two. States of a Simple System (3 Jurisdictions, 2 Laws)

\begin{tabular}{|c|c|c|c|c|c|c|c|}
\hline 1 & $\begin{array}{lll}0 & 0 & 0 \\
0 & 0 & 0\end{array}$ & 17 & $\begin{array}{lll}0 & 0 & 0 \\
0 & 1 & 1\end{array}$ & 33 & $\begin{array}{llll}0 & 1 & 1 \\
0 & 0 & 1\end{array}$ & 49 & $\begin{array}{lll}0 & 0 & 1 \\
1 & 1 & 0\end{array}$ \\
\hline 2 & $\begin{array}{lll}1 & 0 & 0 \\
0 & 0 & 0\end{array}$ & 18 & $\begin{array}{llll}0 & 0 & 0 \\
1 & 1 & 1\end{array}$ & 34 & $\begin{array}{lll}1 & 0 & 0 \\
1 & 1 & 0\end{array}$ & 50 & $\begin{array}{lll}0 & 1 & 0 \\
1 & 0 & 1\end{array}$ \\
\hline 3 & $\begin{array}{lll}0 & 1 & 0 \\
0 & 0 & 0\end{array}$ & 19 & $\begin{array}{lll}1 & 0 & 0 \\
0 & 1 & 0\end{array}$ & 35 & $\begin{array}{lll}100 & 0 \\
101\end{array}$ & 51 & $\begin{array}{lll}1 & 0 & 0 \\
0 & 1 & 1\end{array}$ \\
\hline 4 & $\begin{array}{llll}0 & 0 & 1 \\
0 & 0 & 0\end{array}$ & 20 & $\begin{array}{lll}1 & 0 & 0 \\
0 & 0 & 1\end{array}$ & 36 & $\begin{array}{llll}0 & 1 & 0 \\
1 & 1 & 0\end{array}$ & 52 & $\begin{array}{ll}11 & 1 \\
1 & 0\end{array}$ \\
\hline 5 & $\begin{array}{lll}0 & 0 & 0 \\
1 & 0 & 0\end{array}$ & 21 & $\begin{array}{lll}0 & 1 & 0 \\
0 & 0 & 1\end{array}$ & 37 & $\begin{array}{lll}0 & 1 & 0 \\
0 & 1 & 1\end{array}$ & 53 & $\begin{array}{ll}1 & 1 \\
0 & 1\end{array}$ \\
\hline 6 & $\begin{array}{llll}0 & 0 & 0 \\
0 & 1 & 0\end{array}$ & 22 & $\begin{array}{lll}0 & 1 & 0 \\
1 & 0 & 0\end{array}$ & 38 & $\begin{array}{lll}0 & 0 & 1 \\
1 & 0 & 1\end{array}$ & 54 & $\begin{array}{ll}1 & 1 \\
0 & 0\end{array}$ \\
\hline 7 & $\begin{array}{lll}0 & 0 & 0 \\
0 & 0 & 1\end{array}$ & 23 & $\begin{array}{lll}0 & 0 & 1 \\
1 & 0 & 0\end{array}$ & 39 & $\begin{array}{lll}0 & 0 & 1 \\
0 & 1 & 1\end{array}$ & 55 & $\begin{array}{ll}1 & 0 \\
1 & 1\end{array}$ \\
\hline 8 & $\begin{array}{lll}1 & 0 & 0 \\
1 & 0 & 0\end{array}$ & 24 & $\begin{array}{llll}0 & 0 & 1 \\
0 & 1 & 0\end{array}$ & 40 & $\begin{array}{lll}1 & 1 & 0 \\
1 & 0 & 1\end{array}$ & 56 & $\begin{array}{lll}0 & 1 \\
1 & 1\end{array}$ \\
\hline 9 & $\begin{array}{lll}0 & 1 & 0 \\
0 & 1 & 0\end{array}$ & 25 & $\begin{array}{lll}1 & 1 & 0 \\
1 & 1 & 0\end{array}$ & 41 & $\begin{array}{lll}1 & 0 & 1 \\
1 & 1 & 0\end{array}$ & 57 & $\begin{array}{ll}0 & 0 \\
1 & 1\end{array}$ \\
\hline 10 & $\begin{array}{llll}0 & 0 & 1 \\
0 & 0 & 1\end{array}$ & 26 & $\begin{array}{lll}1 & 0 & 1 \\
1 & 0 & 1\end{array}$ & 42 & $\begin{array}{lll}1 & 1 & 0 \\
0 & 1 & 1\end{array}$ & 58 & $\begin{array}{ll}1 & 1 \\
0 & 1\end{array}$ \\
\hline 11 & $\begin{array}{lll}1 & 1 & 0 \\
0 & 0 & 0\end{array}$ & 27 & $\begin{array}{llll}0 & 1 & 1 \\
0 & 1 & 1\end{array}$ & 43 & $\begin{array}{lll}0 & 1 & 1 \\
1 & 1 & 0\end{array}$ & 59 & $\begin{array}{ll}1 & 1 \\
1 & 0\end{array}$ \\
\hline 12 & $\begin{array}{llll}1 & 0 & 1 \\
0 & 0 & 0\end{array}$ & 28 & $\begin{array}{lll}1 & 1 & 0 \\
1 & 0 & 0\end{array}$ & 44 & $\begin{array}{llll}1 & 0 & 1 \\
0 & 1 & 1\end{array}$ & 60 & $\begin{array}{ll}1 & 1 \\
1 & 1\end{array}$ \\
\hline 13 & $\begin{array}{llll}0 & 1 & 1 \\
0 & 0 & 0\end{array}$ & 29 & $\begin{array}{lll}1 & 0 & 1 \\
1 & 0 & 0\end{array}$ & 45 & $\begin{array}{lll}0 & 1 & 1 \\
1 & 0 & 1\end{array}$ & 61 & $\begin{array}{ll}0 & 1 \\
1 & 1\end{array}$ \\
\hline 14 & $\begin{array}{lll}1 & 1 & 1 \\
0 & 0 & 0\end{array}$ & 30 & $\begin{array}{lll}1 & 1 & 0 \\
0 & 1 & 0\end{array}$ & 46 & $\begin{array}{lll}1 & 1 & 0 \\
0 & 0 & 1\end{array}$ & 62 & $\begin{array}{ll}10 \\
11\end{array}$ \\
\hline 15 & $\begin{array}{lll}0 & 0 & 0 \\
1 & 1 & 0\end{array}$ & 31 & $\begin{array}{llll}0 & 1 & 1 \\
0 & 1 & 0\end{array}$ & 47 & $\begin{array}{llll}1 & 0 & 1 \\
0 & 1 & 0\end{array}$ & 63 & \\
\hline 16 & $\begin{array}{llll}0 & 0 & 0 \\
1 & 0 & 1\end{array}$ & 32 & $\begin{array}{lll}1 & 0 & 1 \\
0 & 0 & 1\end{array}$ & 48 & $\begin{array}{lll}0 & 1 & 1 \\
1 & 0 & 0\end{array}$ & 64 & \\
\hline
\end{tabular}

Key: for each state, row $1=$ law 1 , row $2=$ law 2; col. $1=$ jurisdiction $A$, col. $2=$ jurisdiction $B$, col. $3=$ jurisdiction $C ; 0=$ no law, $1=$ law

\section{B. Simulating Competition}

We can now construct the matrix that generates the process, tells us how and when the process is likely to move, and can be used to compute the steady state. This special generator matrix neatly describes an evolutionary process, for its entries are forces competing to 
move the system. It reflects local and not global changes, treating all the laws in all the jurisdictions but one as frozen. The text describes the system's essentials; the notes present the functional form from which the entries in the matrix are derived. To operationalize a Markov model as a "test" to resolve the state competition debate would require a vast number of observations of the frequency with which legislatures consider and reconsider particular statutes and with which those laws are actually changed. I cannot even begin to undertake such a task, and instead I simulate a system's motion with processes whose transition probabilities are not empirically derived. The model's value is therefore primarily heuristic. It pinpoints the behavioral assumptions on which hypotheses of the optimality and stability of state competition must be based, as well as the impact that changing crucial variables and assumptions will have on the process, within the general framework of our understanding of the corporate charter market.

To capture state competition in the generator matrix of the Markov process, the competing forces must be a function of the number of other jurisdictions having particular laws and the array of laws in the jurisdiction considering the change. As the number of jurisdictions with a given law increases, this environment has a greater influence on a jurisdiction's decision to retain, repeal, or adopt that law. The jurisdiction's own laws temper an automatic reaction to the situation in the other jurisdictions. For example, in some simulations I assume that less weight is given to the law's absence in other jurisdictions if the jurisdiction in which legislative action is under consideration already has the law in place.

To incorporate the notion that it is costly to change the status quo, I assign positive weights to all states. This is plausible because adopting or repealing a law takes time and money and involves risks. Legislators have to engage in bargaining and may lose constituents' votes in a future election. I typically make the likelihood of repeal a function of the state by making it inversely related to the number of other jurisdictions with the law. In addition, to explore the valuemaximizing hypothesis, I vary the assumption of whether repeal is as likely as adoption.

Five sets of assumptions from which values of a generator matrix are derived, and their corresponding steady states, will be examined. Recall that to use a Markov process, legal change is incremental. Accordingly, the system's movement is restricted; it cannot move from one state to any other state. A move of the system consists of one jurisdiction either retaining the status quo or changing it by either 
adopting or repealing a statute. ${ }^{90}$ For example, from state nineteen, in which jurisdiction $A$ has law 1 and $B$ has law 2, the system can move to one of six other states (states two, six, thirty, thirty-four, fortyseven, and fifty-one); either $A$ can repeal law 1 or adopt law 2, $B$ can repeal law 2 or adopt law 1, or $C$ can adopt either law 1 or law 2 . The system can also remain in state nineteen.

The first three simulated processes assume that the three jurisdictions are identical-that is, the transitions for one jurisdiction adopting or repealing a law are the same as the transitions for any other jurisdiction. Within this general symmetrical framework, three alternative generator matrices are constructed, depicting various patterns of legislative behavior to approximate, by degrees, state competition. In the first, the forces compelling a statute's adoption or its repeal are symmetrical. A symmetry restriction equates the costs of adopting a law and of repealing it. Thus, the status quo changes-a law is either repealed or adopted-with the same frequency. Two factors affect the legislature's decision: the number of other jurisdictions with the statute, a feature that captures the notion of imitation, that state competition entails jurisdictions reacting to what others do, and the state of the jurisdiction contemplating legislative action. ${ }^{91}$ The symmetry condition on the direction of change in the first process is equivalent

90 This is not as restrictive an assumption as it appears because consideration of changes is controlled by the arrival process; given that this is a continuous-time model and the process is Poisson, it is technically possible for several changes to occur very close in time, in keeping with a legislature's deliberation on a package of corporate law reforms.

91 The desirable relation, $g(n)$, between the jurisdiction's response and the state of other jurisdictions must be an increasing function that is always positive, but always less than one. In this way, the jurisdictions have some stochastic independence from imitation: $A$ jurisdiction may adopt a law even though no other jurisdiction has the law, and it may not adopt a law even though all other jurisdictions have the law. The specific form I used to derive transition values (the entries in the generator matrix, $A$ ) to solve for the steady state is:

$a_{i j}=\sum_{\mathrm{k}=1}^{2} g_{k}\left(n_{k}\right)+s_{i j k}$, all $i \neq j$ where $k$ indexes the two laws and $g_{k}\left(n_{k}\right)=\left(\frac{N i j+1}{4}\right)^{3}, N_{i j}$ is the number of other jurisdictions, besides the jurisdiction considering legislative action, with law $k$ in the origin state $i$ and destination state $j$, and $s_{i j}$ indexes the state of the jurisdiction considering action. The denominator of $g, 4$, equals $N+1$, where $N=$ the maximum number of jurisdictions, a form chosen so that $g(n)$ would take the appropriate shape were more jurisdictions included in the system. There are only three values of $g_{k}\left(n_{k}\right)$ because $n$ has only three possible values, $(0,1,2)$, and these are, correspondingly $(.0156, .125, .4219)$. There are 8 possible $s_{i j}$ 's, as $i$ and $j$ index 4 states: no law, law 1, law 2, both laws; the $k$ index for the law under consideration matters only in some of the nonrandom processes. In the random process, $s_{i j}$ takes on one of two values, 0 when the move is between a state of no and one law, and .0156 when the move is between a state of one and both laws. The diagonal entries of $A, a_{i j}$ for all $i=$ $j$, equal the negative of the sum of the other entries in the row. The rows of $A$ sum to zero, for it is the derivative of the matrix of transition probabilities when the process has yet to begin, that is, when time $=0$. The steady state is found by solving the system of equations $v A=0$, where $v$ is the vector of the probabilities of the stationary distribution. 
to assuming that legislators cannot distinguish a value-maximizing law from a non-value-maximizing one. A legislature that is blind to a law's value-maximizing properties would not know the effects of the law it is considering, and under such circumstances, it is possible to assume that any change in the status quo is equally likely. I will refer to this process as a random process.

The second process retains the assumption that jurisdictions are identical, but adjusts response rates downward for repealing a law, in a negative relation to the number of other jurisdictions with the law (that is, repeal is less likely if two other jurisdictions have the law than if no one else has the law) ${ }^{92}$ This is intended to represent the behavior of a weakly-optimizing legislature. If a law under consideration is a value-maximizing one, then for an optimizing legislature, the law's adoption will be more likely than its repeal. Moreover, if a law's persistence across jurisdictions is a signal of its welfare-enhancing properties, then even if the legislators cannot identify a value-maximizing law, they can hope to do so by imitating other jurisdictions. However, consistent with A.3, neither possibility, repeal or adoption, is undertaken with probability one or zero. I will refer to this process as the weak $v-m$ process, where $v-m$ stands for value-maximizing. It is a weak story of charter market optimality because there is no guarantee of a statute's passage nor of its retention, yet its movement is weighted toward optimality by the asymmetry in repeal and adoption response rates. ${ }^{93}$ One way to interpret this model is that legislators know one of the two laws is value-maximizing but they do not know which one it is, and consequently, they treat adoption more favorably than repeal to be on the safe side. The findings of the empirical research-no negative abnormal returns and sometimes positive abnormal returns upon reincorporation-seem to fit most closely with such a story.

The third process modeled, in which the jurisdictions are interchangeable, is intended to present a stronger value-maximizing world. To investigate optimality, only one of the two laws, law 1, is assumed to be value-maximizing, and the other law, law 2, is assumed to be

92 The $s_{i j k}$ values are adjusted so that $s_{i j k}=1$, all $k$, for an adoption but $s_{i j k}=-g_{k}\left(n_{k}\right)$ for a repeal.

93 Assuming the costs of repeal and adoption are asymmetrical may be more realistic than assuming symmetry. Although I consider the different structures to be related to the substantive content of the law as value-maximizing, this need not be the case. For instance, unspecified procedural factors, such as the growth of vested interests, might make repeal more difficult than adoption. Cf. Walker, The Origins and Maintenance of Interest Groups in America, 77 Amer. Pol. Sci. Rev. 390 (1983)(organized public interest groups arise after passage of legislation). Clearly, what is needed is what we do not have, a theory of the production function of a state legislature. 
non-value-maximizing. This is in keeping with the fact that many jurisdictions have adopted takeover statutes whose benefits to shareholders are disputed. In contrast to the weak v-m process, in which the legislature cannot distinguish perfectly between laws, in this strong $\mathrm{v}-\mathrm{m}$ process, the adoption and repeal rates are further adjusted to favor having the value-maximizing law. ${ }^{94}$ It is more plausible to label the favored law as value-maximizing rather than managerialist because the empirical literature has only been able to document positive rather than negative effects on firms from changing legal regimes.

Table Three lists the stationary distributions for the different processes. In the random process, the system stays, as expected, in each state an equal proportion of the time. In the weak v-m process, the steady state looks quite different, and accords with intuition. The system spends increasingly more time in the states in which more jurisdictions have both laws, and in particular, all three jurisdictions have both laws for about one-third of the time. The system is never in the state in which no jurisdiction has any law. However, as we would expect, the strong $v-m$ process spends less time in the states with the non-value-maximizing law and more time in the states with only the value-maximizing law, than does the weak v-m process. Comparing the limiting probabilities of states fourteen and eighteen makes the point graphically: The system shifts from spending an approximately equal time in these two states in the weak $v-m$ process to spending about twenty times as much time in state fourteen in which all jurisdictions have the value-maximizing law than in state eighteen in which they all have the non-value-maximizing law in the strong v-m process, which represents a threefold increase across the processes. The strong v-m system's tendency is to spend a longer period of time in the long run in the more optimal states, but a substantial proportion of time is spent in suboptimal states. Moreover, the steady state of both $\mathrm{v}-\mathrm{m}$ processes is more in accord with the observed S-shaped diffusion pattern in corporate law reforms, in which over time more, though not all, states come to have a law, than is the steady state of the random process.

To increase the realism of the simulated systems, two additional generator matrices were created in which the process incorporates different response rates for the jurisdictions. In keeping with the Dela-

\footnotetext{
94 The response values for the value-maximizing law, which I assign as law $1, g_{1}\left(n_{1}\right)$, follow those for the undifferentiated processes, see supra note 91 . The response values for law 2, $g_{2}\left(n_{2}\right)$ are simply $1 / 2$ of those for law $1,(.0078, .0625, .2109)$ for $n=(0,1,2)$ respectively. The $s_{i j k}$, when the move is to adopt, equal 1 for law $1(k=1)$ and .5 for law $2(k=2)$; when the move is to repeal, $s_{i j k}=-g_{k}\left(n_{k}\right)$, where $k$ is the law to be repealed.
} 
ware phenomenon, the probabilities for one of the jurisdiction's actions are changed. For jurisdiction $A$, a statute's adoption is more, and its repeal less, likely than for the other two jurisdictions. ${ }^{95}$ In addition, the probabilities for the reactions of the other two jurisdictions are altered to make the statute's adoption more, and its repeal less, likely when $A$ has adopted the law. This process captures the idea of innovation, in a limited way, in addition to imitation, for the first jurisdiction has a higher probability of adopting a law when no other jurisdiction has the law as well as a lower likelihood of repeal. I will call this the Delaware process. The final process combines the features of the Delaware and the strong $v-m$ processes. Jurisdiction $A$ 's differential adoption and repeal rates and correspondingly its effect on the other jurisdictions, are adjusted to favor the value-maximizing law, law 1 , and to disfavor law 2, the non-value-maximizing law, to a greater extent than the other two jurisdictions. ${ }^{96}$ I will call this the strong Delaware process.

As Table Three indicates, this change away from anonymity of jurisdictions intensifies the results of the $\mathrm{v}-\mathrm{m}$ processes. The same relation in the steady state holds between the different states: the frequencies are substantially greater for the states in which two or three jurisdictions have both laws than for the states in which only one jurisdiction has the law, and in the strong Delaware process, they are even greater for states with the value-maximizing law than those with the non-value-maximizing law. However, the differential between these sets of states is greater in the Delaware processes than in their corresponding v-m processes, as is the actual frequency spent in the states in which all three jurisdictions have a law (compare, for example, the limiting probabilities of states fourteen, eighteen, and sixtyfour). The time spent in states in which only two jurisdictions have a law is less in the Delaware processes than in the corresponding v-m processes. Thus, the Delaware processes result in greater uniformity in corporation codes than the anonymous $\mathrm{v}-\mathrm{m}$ processes.

95 If the jurisdiction is Delaware (where I assign the first jurisdiction to be "Delaware") $s_{i j k}$ $=2$, all $k$, if the move is to adopt, $s_{i j k}=-v g_{k}\left(n_{k}\right)$ if the move is to repeal, where $v$ takes the values $(5 / 4,25 / 24,1015 / 1000)$ for $n=(0,1,2)$ respectively. If the jurisdiction is other than Delaware and Delaware does not have the law, the $s_{i j k}$ 's are the same as those for the analogous weak v-m process, see supra notes 91-92, 94. If the jurisdiction is not Delaware but Delaware has the law, then $s_{i j k}=3 / 2$ if the move is to adopt and $s_{i j}=-w g_{k}\left(n_{k}\right)$ if the move is to repeal, where $w$ takes the values $(1,33 / 32,101 / 100)$ for $n=(0,1,2)$ respectively.

96 Entries for the value-maximizing law are unchanged except they now follow the analogous strong v-m process. Entries for the non-value-maximizing law are adjusted as follows. For Delaware, $s_{i j 2}=1 / 4$ for adoption and $s_{i j 2}=-(1 / 2) v g_{k}\left(n_{k}\right)$ for repeal. For the other jurisdictions when Delaware has the non-value-maximizing law, $s_{i j k}=1 / 2$ for adoption and $s_{i j k}$ $=-(1 / 2) w g_{k}\left(n_{k}\right)$ for repeal. 
Table Three. Stationary Distributions of a Simple System

\begin{tabular}{|c|c|c|c|c|c|}
\hline & Random & Weak $v-m$ & Strong $v-m$ & Delaware & Strong Del. \\
\hline$V 1$ & .015616 & .000000 & .000000 & .000000 & .000000 \\
\hline$V 2$ & .015669 & .000003 & .000003 & .000001 & .000001 \\
\hline$V 3$ & .015617 & .000003 & .000003 & .000001 & .000001 \\
\hline$V 4$ & .015641 & .000003 & .000003 & .000001 & .000001 \\
\hline$V 5$ & .015572 & .000003 & .000001 & .000001 & .000000 \\
\hline$V 6$ & .015618 & .000003 & .000001 & .000001 & .000000 \\
\hline$V 7$ & .015579 & .000003 & .000001 & .000001 & .000000 \\
\hline 18 & .015639 & .000204 & .000138 & .000067 & .000057 \\
\hline$V 9$ & .015642 & .000204 & .000138 & .000057 & .000072 \\
\hline$V 10$ & .015630 & .000204 & .000138 & .000057 & .000072 \\
\hline$V 11$ & .015693 & .000156 & .000298 & .000098 & .000145 \\
\hline$V 12$ & .015670 & .000140 & .000298 & .000098 & .000145 \\
\hline$V 13$ & .015645 & .000140 & .000298 & .000042 & .000322 \\
\hline$V 14$ & .015680 & .006062 & .022015 & .003560 & .028857 \\
\hline$V 15$ & .015558 & .000156 & .000039 & .000053 & .000013 \\
\hline$V 16$ & .015522 & .000156 & .000039 & .000053 & .000013 \\
\hline$V 17$ & .015567 & .000156 & .000039 & .000043 & .000019 \\
\hline$V 18$ & .015489 & .006071 & .000992 & .003478 & .000389 \\
\hline$V 19$ & .015699 & .000037 & .000027 & .000022 & .000012 \\
\hline$V 20$ & .015637 & .000037 & .000027 & .000022 & .000012 \\
\hline$V 21$ & .015565 & .000037 & .000027 & .000023 & .000012 \\
\hline$V 22$ & .015556 & .000037 & .000027 & .000010 & .000007 \\
\hline$V 23$ & .015619 & .000037 & .000027 & .000010 & .000007 \\
\hline$V 24$ & .015640 & .000037 & .000027 & .000023 & .000012 \\
\hline$V 25$ & .015662 & .015268 & .013060 & .013656 & .010293 \\
\hline$V 26$ & .015665 & .015265 & .013060 & .013656 & .010293 \\
\hline$V 27$ & .015623 & .015265 & .013060 & .007830 & .009974 \\
\hline$V 28$ & .015642 & .002046 & .002606 & .000977 & .001488 \\
\hline$V 29$ & .015658 & .002041 & .002606 & .000977 & .001488 \\
\hline$V 30$ & .015986 & .002045 & .002606 & .000844 & .001959 \\
\hline$V 31$ & .015655 & .002041 & .002606 & .000791 & $\cdot .001801$ \\
\hline$V 32$ & .015660 & .002041 & .002606 & .000844 & .001960 \\
\hline$V 33$ & .015630 & .002041 & .002606 & .000791 & .001801 \\
\hline$V 34$ & .015641 & .002045 & .000766 & .000964 & .000387 \\
\hline$V 35$ & .015621 & .002045 & .000766 & .000964 & .000387 \\
\hline$V 36$ & .015459 & .002045 & .000766 & .000816 & .000334 \\
\hline$V 37$ & .015478 & .002045 & .000766 & .000796 & .000452 \\
\hline$V 38$ & .015611 & .002045 & .000766 & .000816 & .000334 \\
\hline$V 39$ & .015627 & .002045 & .000766 & .000796 & .000452 \\
\hline$V 40$ & .015621 & .006132 & .004959 & .004809 & .003381 \\
\hline$V 41$ & .015665 & .006128 & .004959 & .004808 & .003381 \\
\hline$V 42$ & .015682 & .006132 & .004959 & .003663 & .004454 \\
\hline$V 43$ & .015601 & .006129 & .004959 & .003510 & .002598 \\
\hline$V 44$ & .015666 & .006129 & .004959 & .003663 & .004454 \\
\hline$V 45$ & .015609 & .006128 & .004959 & .003510 & .002598 \\
\hline$V 46$ & .015651 & .000471 & .000603 & .000909 & .000396 \\
\hline$V 47$ & .015684 & .000465 & .000603 & .000909 & .000396 \\
\hline$V 48$ & .015624 & .000465 & .000603 & .000171 & .000223 \\
\hline$V 49$ & .015608 & .000470 & .000223 & .000216 & .000092 \\
\hline$V 50$ & .015453 & .000471 & .000223 & .000216 & .000092 \\
\hline$V 51$ & .015634 & .000471 & .000223 & .000181 & .000144 \\
\hline$V 52$ & .015665 & .020387 & .047908 & .016095 & .046705 \\
\hline$V 53$ & .015737 & .020386 & .047908 & .014007 & .062300 \\
\hline$V 54$ & .015668 & .020387 & .047908 & .014008 & .062301 \\
\hline$V 55$ & .015614 & .020382 & .005708 & .016025 & .003164 \\
\hline$V 56$ & .015079 & .020382 & .005708 & .013722 & .002736 \\
\hline$V 57$ & .015603 & .020381 & .005708 & .013721 & .002736 \\
\hline$V 58$ & .015701 & .072697 & .108831 & .057988 & .140620 \\
\hline$V 59$ & .015683 & .072698 & .108831 & .076030 & .108378 \\
\hline$V 60$ & .015697 & .072698 & .108831 & .076030 & .108379 \\
\hline$V 61$ & .015579 & .072691 & .036300 & .058461 & .021447 \\
\hline$V 62$ & .015681 & .072691 & .036300 & .075904 & .027791 \\
\hline$V 63$ & .015602 & .072697 & .036300 & .075904 & .027792 \\
\hline$V 64$ & .015811 & .317715 & .287520 & .412297 & .289867 \\
\hline
\end{tabular}

Key: $V i=$ limiting probability of state $i$ 
Three conclusions, which are relatively uncontroversial, can be drawn from the simulations of the evolution of a corporate charter market:

1. The steady-state results of the Markov processes that were adopted to incorporate value-maximizing behavior are more in accord with the observed patterns in corporation codes than are those of a random response process.

2. If there is any uncertainty about legislators' ability to identify value-maximizing proposals, such that value-maximizing laws are not adopted for sure and have some positive probability of repeal, then the system will, in the long run, spend some time in suboptimal states.

3. Although heroic assumptions concerning legislative behavior are needed to guarantee that a system will evolve to the optimal state, with relatively weak behavioral assumptions that have a plausible basis, we can construct a dynamic process in which a system spends the greater proportion of its time in the more optimal states (states in which most or all jurisdictions adopt value-maximizing laws).

\section{Policy Implications of The New Learning on STAte COMPETITION (OR WHERE DO WE GO FROM HERE?)}

The new learning on state competition provides us with a good understanding of the economics, and some inkling of the political dynamics, of the corporate charter market. What conclusions can we draw for public policy?

1. A middle ground between Cary's and Winter's positions on the efficacy of state competition seems to me to be most appropriate. Such a view recognizes that shareholders benefit from state competition, while granting that, on occasion, competition may well produce laws that shareholders in some firms would not choose to adopt voluntarily. To review the data informing this conclusion:

(i) Event studies indicate that state competition does not harm shareholders. None of the studies found any negative effect on investor wealth from state regulation, whether they investigated changes made by the states in statutes or doctrine, or changes made by firms in their choice of incorporation state, and more importantly, they found a positive effect of reincorporation on stock prices.

(ii) There is a plausible logical scenario, supported by anecdotal evidence, that suggests that managers promote second generation takeover statutes because they cannot obtain shareholder approval for the tactics these laws codify, although statistical tests related to this thesis were inconclusive. 
(iii) There is good reason to believe that the political equilibrium in Delaware differs from that of other states when it comes to a potentially managerialist provision like a second generation takeover statute, because its diverse corporate constituency and the corporate bar's input into the legislative process check any one firm's ability to have a pet bill passed.

(iv) Simple stochastic models of the dynamics of a corporate charter market indicate that the processes that capture some key features of state competition by employing weak behavioral assumptions spend a significant amount of time in the more optimal states, but some time will be spent in suboptimal states, unless we adopt quite strong constraints on legislative behavior, such as perfect foresight, so that value-maximizing laws must always be adopted and never repealed.

Staking out a position somewhere between Cary's and Winter's views-and I locate my position as closer to the Winter than the Cary endpoint of the interval-is not that appealing because it both conveys the appearance of hedging one's bets and requires detailed empirical analysis of individual code provisions before any conclusion can be reached. But it is, in my opinion, the most reasonable position to advocate, given current knowledge. It recognizes the agency problem that Winter's position downplays, while concurring in his assessment of the important advantages derived from having a federal system. A corollary of the position is that we should invest less energy in discussing whether national chartering is needed, ${ }^{97}$ and more in examining state regulation at a micro level, to determine how we can improve the federal system.

2. One method to protect shareholders without having to identify precisely which rules maximize shareholder wealth and which do not, is to require that corporation code amendments entailing a major change in relations between shareholders and managers, where we can intuit conflicting interests, such as second generation takeover stat-

97 Even apart from the lack of empirical support, the analytical case for national chartering, in my opinion, has not been made. Most of the benefits of federalism have been emphasized in the debate, such as the incremental experimentation and innovation in corporate law rules created by having numerous decisionmakers. One benefit often overlooked in the corporate law literature, that I find important, is the supportive relation between a federal structure and individual liberty. Vital state governments can check a powerful national government, (for an interesting effort to revitalize this view of Federalism, see A. Amar, A Neo-Federalist View of Sovereignty and Federalism (draft Aug. 1986)) (available at Cardozo Law Library), just as private organizations also protect individuals from encroachment by the state by counterbalancing the state's power, see J. Coleman, The Asymmetric Society 51 -55 (1982). If corporations were subject to comprehensive national regulation, they would be less effective performers of such a checking function. 
utes, contain opt-in rather than opt-out provisions. ${ }^{98}$ For an opt-in regime can minimize the possibility that management will lobby successfully for legislation that shareholders might not support, since shareholders must explicitly approve the law's application to their firm. An opt-in policy is an extension of the basic feature of corporation codes-that they are enabling. The benefit of this approach is that it is a strategy by which shareholders, rather than managers, lobbyists, or legislators, have the ultimate say on corporate governance by voting. ${ }^{99}$ In addition, by increasing the cost of corporate decisionmaking by requiring a shareholder vote, it tends to add to the stability of the status quo of no shark repellent amendment. ${ }^{100}$ This is a desirable feature if shark repellent amendments are harmful to shareholders. The disadvantage is, for firms whose shareholders want the statute's protection, the cost is greater in an opt-in than an opt-out regime where no such vote is required.

(i) The conventional objection to relying on such a device is that voting is a sham because shareholders lack either the information to vote intelligently or the inclination to expend time and resources to obtain the information. I do not find the claim of massive shareholder ignorance and misinformation compelling. But even if the objection is granted, it can be resolved directly, by ensuring the provision of the pertinent information to investors. ${ }^{101}$ Government intervention is not always necessary to ameliorate a market failure. In this context, insti-

98 Cf. M. Eisenberg, The Structure of the Corporation: A Legal Analysis 88 (1976) (shareholders should vote on fundamental changes). A similarly spirited proposal is to require shareholder approval of defensive tactics, such as poison pills; see SEC Advisory Committee on Tender Offers, Report of Recommendations, reprinted in Fed. Sec. L. Rep. (CCH), Special Report No. 1028, at 37-40 (July 15, 1983) (recommending annual shareholder advisory votes on golden parachutes, standstill agreements, and supermajority and disenfranchisement charter provisions).

99 Delaware's latest revision to its code is a good example of such a policy: It does not eliminate director liability, but rather, it permits a firm to limit its directors' liability by charter amendment. S.B. 533, enacted June 18, 1986, to be codified at Del. Code Ann. tit. 8, $\S 102(\mathrm{~b})(7)$. The political process of this bill provides an interesting comparison with that of other state statutes. In contrast to the adoption of Connecticut's takeover statute, in which the corporate bar organization was excluded from the drafting process, Delaware's director liability statute was approved by the corporate law section of the state bar association prior to its enactment. As Judge Moore informs us in his comments in this symposium, this practice of bar approval is the rule, and not the exception, in Delaware.

100 Cf. Bruff, Legislative Formality, Administrative Rationality, 63 Tex. L. Rev. 207, 218 22 (1984) (describing how government structure mitigates faction and increases stability of legislation).

101 There is no convincing basis for asserting that shareholders will be so overwhelmed by the information that an indirect solution of prohibition should be adopted. Cf. Grether, Schwartz \& Wilde, The Irrelevance of Information Overload: An Analysis of Search and Disclosure, 59 So. Cal. L. Rev. 277 (1986) (questioning the contention of an information-overload problem in commercial law). If the fear is the free rider problem that afficts all voting 
tutional investors, who are typically informed voters, have recently begun to create national organizations for pooling information and research on corporate policies. ${ }^{102}$ These voluntary networks could, in due course, produce substantially more informed voting.

(ii) One potential problem for even informed shareholder voting is that management controls the proxy apparatus. This is a problem because if there are many points in the set of majority-preferred outcomes, then management can place on the agenda the particular proposal that it prefers from the winning set. ${ }^{103}$ But if shareholder preferences are homogeneous-which is a plausible assumption in corporate law for all shareholders have the same goal of equity share price maximization - then the majority-preferred set will consist of a single point and management's control of the agenda cannot determine the outcome.

3. If institutional investors' interests differ sharply from those of individual investors, who are uninformed and/or who do not vote, then reliance on voting rights to protect all shareholders will be unsuccessful. This possibility might conjure up the specter of management agenda manipulation, but if the differences are such that shareholder preferences can be represented as single-peaked, arrayed along a single line-which is reasonable given the value-maximizing goal-then, again, there will be no voting cycle and the shareholders determine the outcome regardless of management's position. The concern is therefore not that the outcome will be chosen by management but that the interest of the majority is in direct conflict with that of the minority. In other contexts where shareholders' interests may differ because of institutional characteristics, such as the different positions of high-and low-tax-bracket investors on distribution policies, there is evidence of a clientele effect, in which investors segregate themselves by firm according to similar interests, and thereby avoid the potential conflict so that majority rule poses no difficulty. ${ }^{104} \mathrm{But}$

processes, supermajority conditions could be attached to the amendment process, although I am skeptical that such a solution would be optimal.

102 For example, in 1985, a group of public and private pension fund trustees formed the Council of Institutional Investors to "protect their rights as shareholders" by collecting data and providing information and consulting services for members. Pension Fund Trustees Form Council, Wash. Post, Jan. 25, 1985, at D1; Institutional Investors Join Forces for Clout, id., May 12, 1985, at F1. See also Appearances Likely to Prove Deceiving When It Comes to T. Boone Pickens, Wall St. J., Aug. 22, 1986, at 6, col. 1 (corporate raider to establish group to lobby for shareholder rights). In addition, the Investor Responsibility Research Center compiles annual reports on institutional investors' voting on corporate governance questions.

103 See K. Shepsle, Institutional Equilibrium and Equilibrium Institutions (draft May 1984) (available at Cardozo Law Library).

104 See Lewellen, Stanley, Lease \& Schlarbaum, Some Direct Evidence on the Dividend Clientele Phenomenon, 33 J. Fin. 1385 (1978). 
this solution may not be available to diffuse the conflict with which we are concerned: For example, takeover policies affect so many firms that clienteles may be unable to form because it may be difficult to exclude investments in targets, assuming they can be identified, and achieve optimal portfolio diversification. The policy punch of these considerations is not clear cut. We may have to rethink the use of majority rule to alter rights in corporate law, for it presupposes shareholder unanimity on ends. But there are at least three factors mitigating such a concern. First, majority rules that permit disproportionate premiums may not be objectionable; the nonpro rata sharing may be a return on the shareholder's investment in information. Such rewards to information-seeking may be necessary for market efficiency. ${ }^{105}$ Second, there have been and may continue to be fundamental changes in the form of ownership of public corporations, such that uninformed investors with small holdings may come to hold shares only indirectly via mutual funds, ${ }^{106}$ which would moot the potential conflict. Third, if prices or some other datum signal to uninformed shareholders the view of the informed, then the voting outcome may be identical to the voting outcome under complete information. ${ }^{107}$

4. When we consider the issue of informed voting by shareholders in light of the politics of Connecticut's second generation takeover statute, a further recommendation is in order: Bills substantively revising corporation codes should be scrutinized and debated in a public hearing. This policy will raise the cost of legislating, but it will also provide a check on the passage of hastily drafted statutes that can have unintended, adverse consequences. A legislature should be more than a clearing house for pork barrel. With a public hearing, a legislature could improve the quality of decisionmaking by drawing on the insights of experts testifying concerning the probable consequences of particular policies in reaching a judgment on a bill. ${ }^{108}$ It would, at least, promote a more active role for the corporate bar in the legisla-

105 See generally Gilson \& Kraakman, The Mechanisms of Market Efficiency, $70 \mathrm{Va}$. L. Rev. 549 (1984) (discussing market efficiency). The rewards may also be shared by the uninformed-some of the information of sophisticated investors will be conveyed in the stock price as they trade, and some uninformed shareholders will tender in two-step offers and receive the same disproportionate share as the informed.

106 See Clark, The Four Stages of Capitalism: Reflections on Investment Management Treatises, 94 Harv. L. Rev. 561, 564-65 (1981).

107 See R. McKelvey \& P. Ordeshook, Information, Electoral Equilibria and the Democratic Ideal (manuscript 1986) (complete information equilibrium attained despite incomplete information as uninformed voters update from very general and cheap information sources such as opinion polls) (available at Cardozo Law Library).

108 See W. Muir, Legislature (1982) (state legislature is a school in which legislators are educated by lobbyists and other informed individuals). 
tive process. The bar's participation offers the benefit that its members represent clients with diverse interests, and a package that meets their approval would be more likely attuned to the problems of unintended consequences, if not more balanced in its effects, than a draft submitted by one anxious corporation. ${ }^{109}$ In addition, hearings create a record of a proposal's strengths and weaknesses that shareholders can use in assessing whether to agree to conform their charters to the revised codes.

5. A middle ground on state competition has specific implications for the direction of research. In particular, we need to undertake more comparative studies of the political process across states and statutes, and compile information on shareholder attitudes and voting patterns on different corporate policies or management actions. To the extent that the events of importance involve evolutionary processes, we may need to seek out new and refine existing techniques on how to determine the impact of specific policies on investor wealth. Without such information, discussion will devolve into ill-informed a priori assertions about the probable effects of particular rules, and we will correspondingly be unable to raise the quality of public decisionmaking.

109 The introduction of attorneys obviously creates the potential for additional agency problems concerning their advocacy of the client's interests in the legislative process. In addition to the constraints placed on attorneys from the forces of state competition, see supra note 39, a competitive market for legal services should constrain attorneys from favoring their own interests at a cost to shareholders. 
HeinOnline -- 8 Cardozo L. Rev. 758 1986-1987 